\title{
LEON KOZŁOWSKI (1892-1944) - KRAKOWSKI ETAP ŻYCIA NAUKOWCA, ŻOŁNIERZA, POLITYKA
}

\author{
LEON KOZŁOWSKI (1892-1944): THE KRAKÓW PHASE IN THE LIFE \\ OF THE RESEARCHER, SOLDIER, AND POLITICIAN
}

Leon Kozłowski (1892-1944), the outstanding prehistorian, soldier, and politician, was connected with Kraków from the beginning of his studies until he obtained his postdoctoral degree. He studied natural sciences and then archaeology at the Jagiellonian University while being also an unofficial assistant at the Archaeological Museum of the Academy of Arts and Sciences in Kraków. The Academy appointed him to explore Lusatian cemeteries near Tarnobrzeg, to excavate a Palaeolithic site in Jaksice (former Miechów district), megalithic graves in Kuyavia, and the Mammoth Cave in the Polish Jura. He collected materials for the Academy during a scientific expedition to the Crimea and the Caucasus organized by Robert Rudolf Schmidt (1882-1950) from the University of Tübingen. During the First World War, Kozłowski joined the Polish Legions and was thus involved in the struggle for Polish independence. He moved to Warsaw to write his doctoral thesis based on the collection of the Erazm Majewski Museum and then defended it in Tübingen. After he gained his postdoctoral degree in Kraków, he took the chair of prehistory in Lwów/Lviv and his contacts with the Jagiellonian University and the Academy of Arts and Sciences in Kraków came to a close. It was only in 1935 that he was elected a corresponding member of the Academy.

KEY WORDS: Leon Kozłowski (1892-1944), Kraków, the Jagiellonian University, the Academy of Arts and Sciences, World War I, history of archaeology

\section{PIERWSZE LATA}

Leon Kozłowski (ryc. 1) urodził się w 1892 roku w Rembieszycach, w powiecie jędrzejowskim, w guberni kieleckiej. Dzieciństwo i wczesną młodość spędził najpierw w majątku matki w Przybysławicach, w powiecie miechowskim, a później w Kielcach. Już wtedy zainteresowanie prehistorią wzbudził $\mathrm{w}$ nim badacz jaskiń ojcowskich, Stanisław Jan Czarnowski (1847-1929). Później, przebywając w Warszawie jako uczeń gimnazjum, Leon Kozłowski poznał swojego mistrza, Erazma Majewskiego (1858-1922), prehistoryka, twórcę warszawskiego Muzeum Archeologicznego i redaktora Światowita. Majewski zgromadził wokół siebie grupę młodych badaczy, późniejszych wybitnych polskich archeologów, do której obok Kozłowskiego należeli również: Marian Himner (1887-1916), Stefan Krukowski (1890-1982) i Ludwik Sawicki (1893-1972). Warszawski prehistoryk wywarł duży wpływ na naukowy rozwój Kozłowskiego. Będąc jego nauczycielem, umożliwiał mu kontakt ze zbiorami zabytków, udostępniał własną 
bibliotekę naukową, wysyłał na wykopaliska, a także publikował ich wyniki. Pod jego wpływem Leon Kozłowski zaczął prowadzić swoje pierwsze badania - w 1909 roku na wydmach w okolicach Warszawy, a w latach 1909-1910, także z polecenia i na koszt Majewskiego, powierzchniowe poszukiwania niedaleko rodzinnych Przybysławic, w rejonie rzeki Dłubni, a także w dorzeczu Przemszy.

Kozłowski, wychowany w rodzinie o patriotycznych tradycjach, od wczesnej młodości zaangażowany był w politykę. W Warszawie działał w związanym z Polską Partią Socjalistyczną nielegalnym Związku Młodzieży Postępowej, za co w 1910 roku został na krótko aresztowany. Po zdaniu matury opuścił Warszawę i udał się najpierw do Przybysławic, a następnie, za namową Majewskiego, podjął studia w Krakowie (Kostrzewski 1946-1947; 1949, 102; Jażdżewski, Jędruszczak 1970, 19; Wrońska 1986, 128-129; Abramowicz 1991, 95; Kozłowski 1996; Lech 1996, 51, 6668; 2001, 136; M. Kozłowski 2005, 19-26; Lech, Piotrowska 2006, 159-165; Kozłowski 2010).

\section{PIERWSZE LATA STUDIÓW NA UNIWERSYTECIE JAGIELLOŃSKIM}

Kraków, do którego w 1910 roku przyjechał Leon Kozłowski, w dziedzinie nauki wysunął się na czołowe miejsce na ziemiach polskich. Kluczowe znaczenie dla tego ośrodka miały dwie instytucje - Uniwersytet Jagielloński i powstała w 1872 roku z Towarzystwa Naukowego Krakowskiego Akademia Umiejętności. Na przełomie XIX i XX wieku Uniwersytet przeżywał złoty okres. Sukcesywnie wzrastała liczba studentów. W Krakowie, obok młodzieży z Galicji, dość licznie uczyła się także pozbawiona polskich uczelni młodzież z Królestwa Polskiego, studiowali tu również młodzi ludzie z terenów Litwy, Wołynia, Podola, a także z zaboru pruskiego. W okresie od 1855 do 1914 roku liczba studentów wzrosła kilkunastokrotnie. Pomimo iż wiedeńskie władze centralne przeznaczały na potrzeby uczelni zbyt niskie, niewystarczające dotacje, w Krakowie budowano gmachy uniwersyteckie, powstawały nowe katedry, gabinety i pracownie. Na przełomie wieków Uniwersytet Jagielloński, także dzięki kadrze naukowej, w gronie której znajdowali się wybitni uczeni pochodzący nie tylko z Galicji, ale również z pozostałych zaborów, stał się w pełni ogólnopolską uczelnią (Dybiec 1979, 20-21, 24-28; Bieńkowski 1983,23-24; Perkowska 1990, 9-19; Stopka, Banach, Dybiec 2000, 98-100, 111-112). Podobny

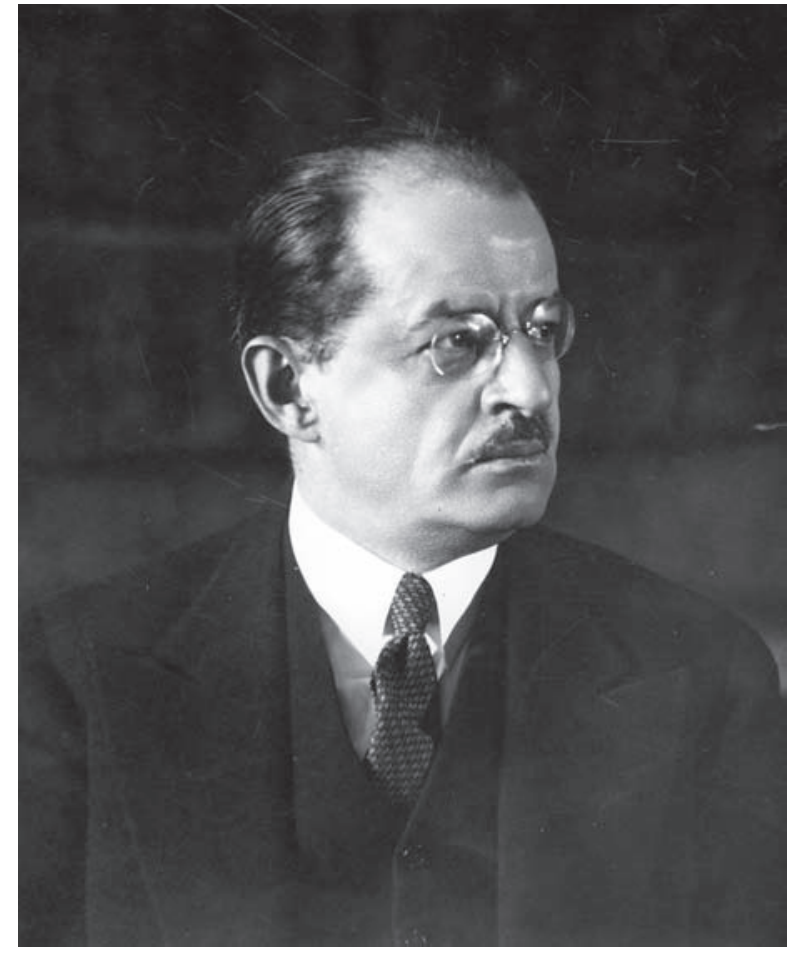

Ryc. 1. Leon Kozłowski (1892-1944) jako premier.

Fot. ze zbiorów Narodowego Archiwum Cyfrowego, sygn. 1-A-1824-2

Fig. 1. Leon Kozłowski (1892-1944) as Poland's Prime Minister. Photo from the collection of the National Digital Archives, catalogue no 1-A-1824-2

charakter miała krakowska Akademia Umiejętności. Rozwijały się w niej liczne uprawiane w tych czasach dyscypliny naukowe, zarówno humanistyczne, jak i przyrodnicze, a jej dorobek naukowy i wydawniczy stał na bardzo wysokim poziomie. Instytucja ta pozostawała w szerokich kontaktach z nauką europejską, a wśród jej członków znajdowali się nie tylko luminarze nauki polskiej, ale i pochodzący z innych krajów wybitni uczeni, jak Ludwik Pasteur (1822-1895) czy Pierre Curie (1859-1906) (Kutrzeba 1939, 3, 50; Hulewicz 1948, 2, 25-28; Bieniarzówna, Małecki 1979, 285-297; Bieńkowski 1983, 31-33; Stachowska 1990; Dybiec 1993, 11-12, 36-37).

Leon Kozłowski rozpoczął studia na Uniwersytecie Jagiellońskim w 1910 roku. Wydział Filozoficzny, na który się zapisał, był wydziałem wielokierunkowym, najliczniejszym spośród czterech wydziałów krakowskiej uczelni ${ }^{1}$. Na przełomie 1913 i 1914 roku

1 Na Uniwersytecie Jagiellońskim w tym okresie istniały cztery wydziały: Teologiczny, Prawniczy, Lekarski i Filozoficzny (Perkowska 1990, 10; Stopka, Banach, Dybiec 2000, 107-108). 
uczyły się na nim 1354 osoby. Aby zostać studentem zwyczajnym, trzeba było legitymować się świadectwem dojrzałości z gimnazjum typu klasycznego. Kozłowski, który ukończył szkołę realną, mógł zapisać się na Uniwersytet tylko jako słuchacz nadzwyczajny (Perkowska 1990, 10-11; M. Kozłowski 2005, 24). W trybie tym, w latach 1910/1911-1912/1913, zaliczył pięć semestrów i dopiero po zdaniu uzupełniających egzaminów z języka łacińskiego, logiki i psychologii w Liceum im. Staszica w Lublinie, w 1913 roku został przyjęty w poczet studentów zwyczajnych. Jako student zwyczajny uczęszczał na wykłady w roku akademickim 1913/14, a także w ciągu jednego semestru w roku 1915/16 (Życiorys L. Kozłowskiego², 1917 r., teczka doktorska, Archiwum UJ, sygn. WF II 504; Perkowska 2007, 182-183; Corpus studiosorum 2009, 538). Absolutorium uzyskał w roku 1916 (Teczka habilitacyjna L. K., Archiwum UJ, sygn. WF II 121; Godlewski 2010).

Na decyzję o podjęciu studiów w Krakowie istotny wpływ miała perspektywa pobierania nauk u profesora Włodzimierza Demetrykiewicza (1859-1937). W 1910 roku Leon Kozłowski pisał do Erazma Majewskiego:

„U profesora Demetrykiewicza byłem i doznałem bardzo uprzejmego przyjęcia. Radzi mi on stanowczo pozostać w Krakowie, co też uczyniłem (...)" (list L. K. do E. Majewskiego, [1910 r.], Teka XV korespondencji E. Majewskiego, Pracownia Dokumentacji Naukowej, Państwowe Muzeum Archeologiczne w Warszawie - dalej: PMA).

Jednak kilka lat później młody archeolog pisał do swojego warszawskiego mistrza, że wiadomości wyniesione z dwuletnich studiów w Krakowie wciąż jeszcze były niewystarczające, a zdobyta wiedza niepełna (list L. K. do E. Majewskiego, 15 I 1913 r., tamże). Demetrykiewicz, jak podawał również będący słuchaczem jego wykładów Józef Kostrzewski (1885-1969), nie był dobrym dydaktykiem (Kostrzewski 1970,61; por. Woźny 2018,217-218). Trzebajednak zaznaczyć, że na stan wiedzy Leona Kozłowskiego z zakresu prehistorii musiał mieć także wpływ fakt, że pierwszy etap jego nauk na Uniwersytecie Jagiellońskim to studia przyrodnicze (początkowo studiował chemię), a wykłady z archeologii prehistorycznej stanowiły jedynie niewielką część wybranych przez

2 W następnych odwołaniach, dla uproszczenia, nazwisko Leona Kozłowskiego będzie zapisywane w formie skróconej, jako inicjały - L. K. niego zajęć. I tak, w pierwszym roku studiów, obok obejmującego tylko dwie godziny tygodniowo kursowego wykładu Demetrykiewicza na temat czasów prehistorycznych na terenach Ziemi Krakowskiej ${ }^{3}$, Kozłowski uczęszczał na zajęcia z wstępu do analizy matematycznej (2 godziny tygodniowo), krystalografii (3 godziny tygodniowo), fizyki doświadczalnej (5 godzin tygodniowo), chemii nieorganicznej (5 godzin tygodniowo), anatomii zwierząt domowych i histologii (3 godziny tygodniowo), a także brał udział $\mathrm{w}$ dwugodzinnych ćwiczeniach $\mathrm{z}$ anatomii. Na liście wykładów, na które się zapisał, wykład profesora Demetrykiewicza znajdował się na ostatnim miejscu (Księga rodowodów studentów, Archiwum UJ, sygn. S II 227). W roku następnym przyszły archeolog słuchał wykładów $\mathrm{z}$ antropologii i antropometrii, a także z zoologii systematycznej, geologii, antropogeografii, mineralogii fizycznej, brał również udział w zajęciach $\mathrm{w}$ pracowni fizycznej. W tym roku w ogóle nie był słuchaczem wykładów z prehistorii (tamże, sygn. S II 235c; Spis wykładów 1911b, 16; 1912, 17; Gedl 1971, 190; 2000, 133). Dopiero w 1912 roku zapisał się na wykład traktujący o początkach sztuki ludów prehistorycznych Europy. Wtedy też, obok kilku innych studentów $\mathrm{UJ}^{4}$, brał udział w nadzorowaniu prac ziemnych prowadzonych na Wawelu w związku z trwającą od kilu lat wielką restauracją zamku (Dziennik dyżurów przy nadzorze prac ziemnych na Wawelu, 1912 r., teczka stanowiska Wawel, Archiwum Muzeum Archeologicznego w Krakowie - dalej: MAK). W tym roku Kozłowski nadal uczęszczał na zajęcia z antropologii i antropometrii, kontynuował naukę zoologii systematycznej, zapisał się na wykłady z geografii dynamicznej i anatomii kręgowców. Ale znów, gdy inne wykłady obejmowały niejednokrotnie nawet pięć godzin tygodniowo, wykład $\mathrm{z}$ archeologii liczył zaledwie dwie (Księga rodowodów studentów, Archiwum UJ, sygn. S II 236b).

Jednak mimo że Leon Kozłowski brał udział w tak niewielu zajęciach prowadzonych przez profesora Demetrykiewicza, bardzo szybko stał się jednym z jego najbliższych uczniów. I choć w ciągu roku akademickiego Włodzimierz Demetrykiewicz miewał kilkudziesięciu studentów, za tych, którzy rzeczywi-

3 Według oficjalnego uniwersyteckiego wykazu był to jedyny wykład Demetrykiewicza w tym roku (Spis wykładów 1910: 15; 1911a: 16).

4 Między innymi przyszłych prehistoryków: Michała Drewki (1887-1964), Romana Jakimowicza (1889-1951) i Józefa Żurowskiego (1892-1936). 
ście zajęli się prehistorią, uważał w tym okresie jedynie Michała Drewkę (1887-1964), późniejszego wieloletniego konserwatora zabytków archeologicznych na Lubelszczyźnie i Wołyniu, oraz właśnie Leona Kozłowskiego (list W. Demetrykiewicza do J. Kostrzewskiego, 27 IV 1913 r., MAK, sygn. SP8/36).

\section{U BOKU WŁODZIMIERZA DEMETRYKIEWICZA. NIEFORMALNA ASYSTENTURA W AKADEMII UMIEJĘTNOŚCI W KRAKOWIE I PIERWSZE BADANIA Z JEJ RAMIENIA}

Włodzimierz Demetrykiewicz, kustosz Muzeum Archeologicznego Akademii Umiejętności, bardzo szybko zaangażował młodego Kozłowskiego do prac w Akademii (ryc. 2), gdzie, obok Michała Drewki, zaczął on pełnić nieformalną funkcję asystenta. Dbając o naukowy rozwój swoich asystentów, Demetrykiewicz nie tylko organizował im zajęcia w Muzeum, ale również zabierał ich na prowadzone przez siebie wykopaliska. Już w 1911 roku Leon Kozłowski brał udział w badaniach Demetrykiewicza na cmentarzysku ciałopalnym kultury łużyckiej w Mydlnikach pod Krakowem [obecnie Kraków-Mydlniki; ryc. 3] (teczka stanowiska Mydlniki-Kraków, MAK; Życiorys L. K., 1917 r., Teczka doktorska, Archiwum UJ, sygn. WF II 504; por. Woźny 2018, 274-275).

W czasie studiów, młody archeolog, delegowany i zaopatrzony przez kustosza Muzeum we wskazówki, prowadził już samodzielne badania terenowe z ramienia Akademii. Wiosną 1912 roku w Gorzycach, w powiecie tarnobrzeskim, natrafiono na zagrożone zniszczeniem przez orkę cmentarzysko ciałopalne kultury łużyckiej (Demetrykiewicz 1897; Nosek 1967, 70). Nie mogąc udać się osobiście na miejsce odkrycia, Demetrykiewicz wysłał do Gorzyc najpierw Michała Drewkę, wtedy studenta czwartego roku, a później, na jego prośbę, również Leona Kozłowskiego. Po przybyciu do Gorzyc Drewko pisał:

„Proszę wysłać Kozłowskiego, bo sam nie mogę się $\mathrm{z}$ tymi garnkami uporać - wszystkie są na kupie jedno tuż koło drugiego, trudno się wyznać jakie przystawki do jakiej należą urny. Albo niech W[ielmożny] Pan Profesor sam przyjedzie choć na krótko - nie chciałbym robić wszystkiego na własną rękę. Sam musiałbym siedzieć na cmentarzysku najmniej tydzień, jak nie więcej. Proszę wysłać Kozłowskiego i dać mu ustnie wiadomości albo odtelegra- fować lub odpisać do poniedziałku (...)" (list M. Drewki do W. Demetrykiewicza, 11 V 1912 r., teczka stanowiska Gorzyce, pow. Tarnobrzeg, MAK).

Reakcja Demetrykiewicza była natychmiastowa i już trzy dni później Drewko opisywał wykopaliska (ryc. 4) prowadzone wspólnie z przybyłym z Krakowa Kozłowskim (list M. Drewki do W. Demetrykiewicza, 14 V 1912 r., tamże). Ten zaś informował profesora:

„Rano od 5tej rozpocząłem wraz z kolegą poszukiwania: przekopaliśmy 25 met[rów] z z zawartością 10 grobów i 38 naczyń. Są to skupienia popielnic pozbawionych prawie przystawek, które przeważnie znajdują się wewnątrz popielnic. Popielnice są (...) pięknie, przeważnie plecionką ornamentowane" (list L. K. do W. Demetrykiewicza, 14 V 1912 r., tamże).

Po zakończeniu wykopalisk w Gorzycach Kozłowski i Drewko udali się do sąsiednich Sokolnik (ryc. 5), gdzie również prowadzili badania na odkrytym tam cmentarzysku prawdopodobnie kultury łużyckiej (Nosek 1967, 70). Później młodzi badacze, zapewne wraz z profesorem Demetrykiewiczem, datowali to cmentarzysko na okres lateński ${ }^{5}$. Badania w Gorzycach i Sokolnikach były finansowane przez Komisję Antropologiczną Akademii Umiejętności. Kozłowski i Drewko przesłali znaleziska do Akademii. Drewko pisał:

„Z Sokolnik wysłałem dwie ostatnie paki z wykopaliskami ważące razem $160 \mathrm{~kg}$ - zatem jest ich razem z wysłanymi przez Kol[egę] Kozłowskiego 15. Właśnie gdy byłem na stacji w Grębowie ładowano 13 pak Kozłowskiego do wagonu (...)" (list M. Drewki do W. Demetrykiewicza, 21 V 1912 r., teczka stanowiska Gorzyce, pow. Tarnobrzeg, MAK).

Łącznie, z obu cmentarzysk, badacze przekazali do Akademii około dwustu naczyń i „,wiele drobnych wyrobów" (Sprawozdania z posiedzeń 1914, IX). Później Kozłowski szacował, że przedmiotów tych było więcej, nawet czterysta naczyń (Życiorys L. K., 1917 r., Teczka doktorska, Archiwum UJ, sygn. WF II 504).

W publikowanych przez Akademię Umiejętności w Krakowie sprawozdaniach napisano, że stanowisko to „pochodzi (...) z epoki La Tène, ma ceramikę ozdobną charakterystycznej formy, a wewnątrz popielnic liczne podarki grobowe z brązu, żelaza i szkła" (Sprawozdanie 1913, 119; Sprawozdania z posiedzeń 1914, IX). 


\section{Jaskinia Peblorska}

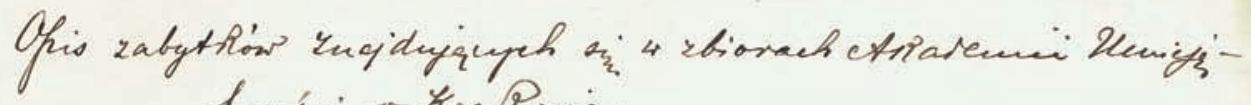
turkex or KradPorries foner Deona Liotorsingo.

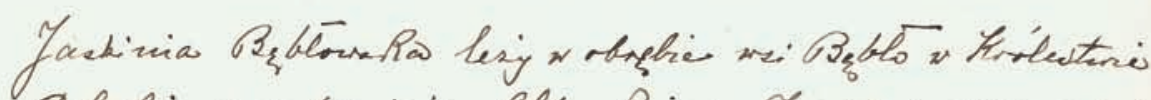

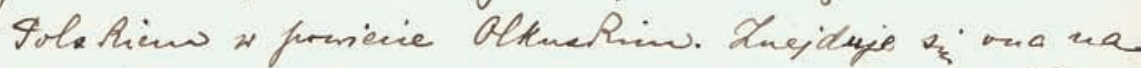

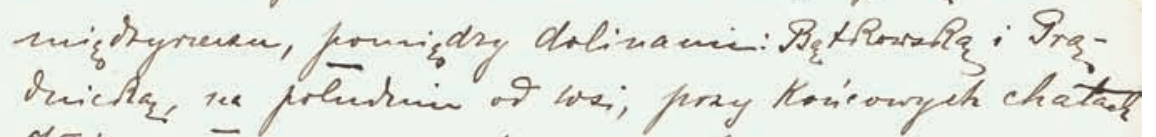

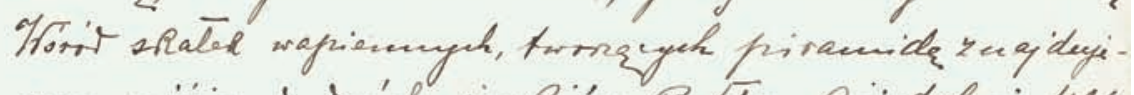

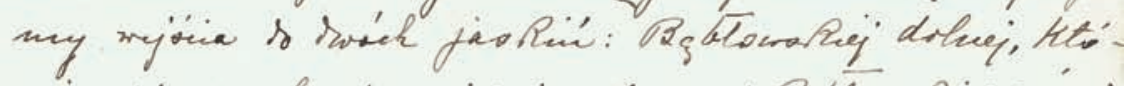

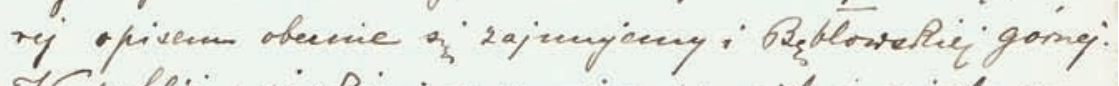
Hf poblini jiskini $x$ vamej we knqidaje os otan.

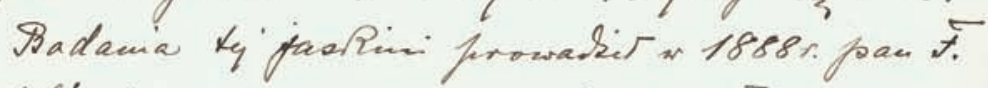
Chwalibog i nierporaes wacry materyat zlinjt w murem

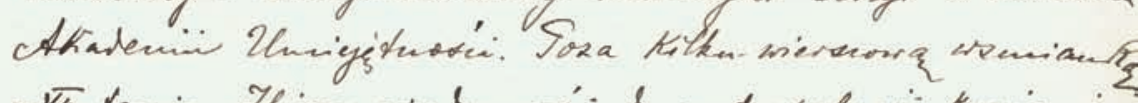

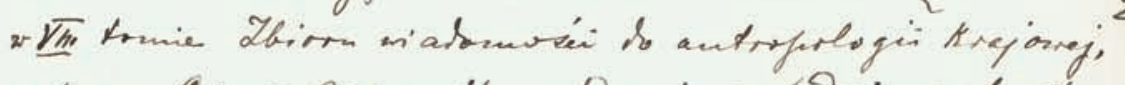

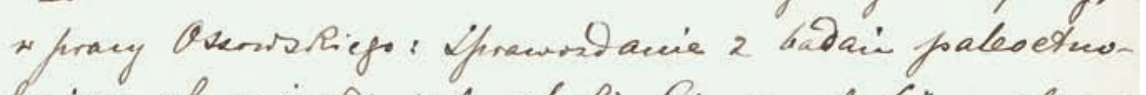

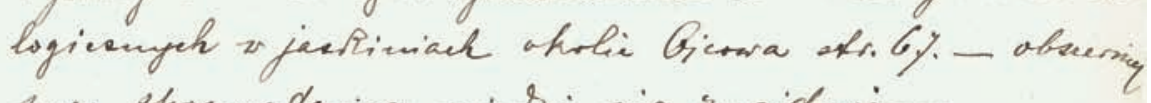

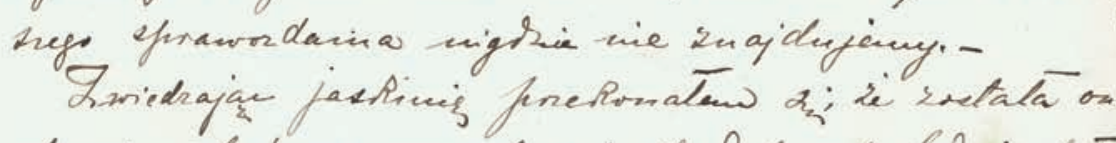

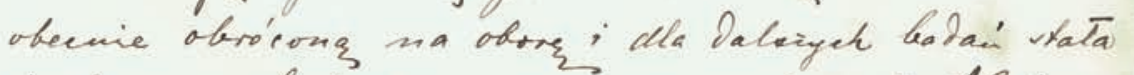

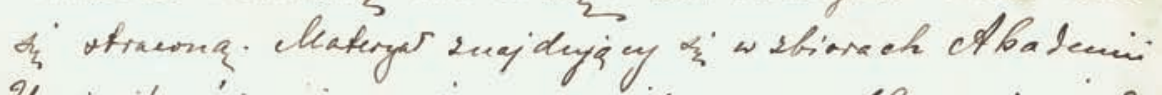

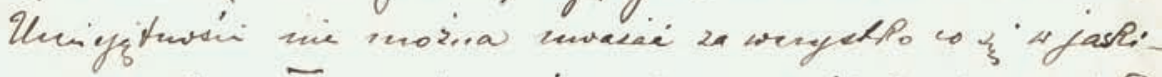

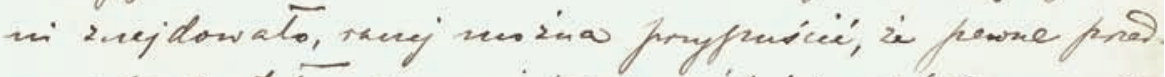

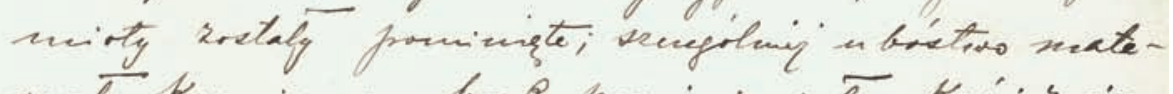

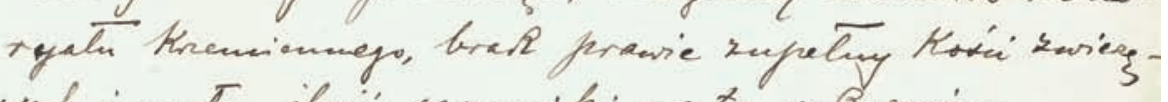
cyole, mata ilowi ceranito: na to wa parajg-

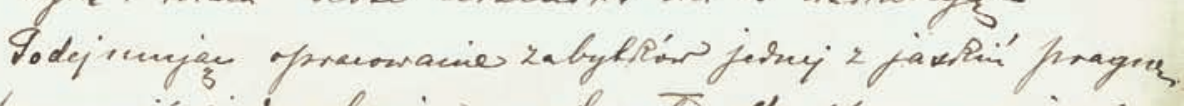

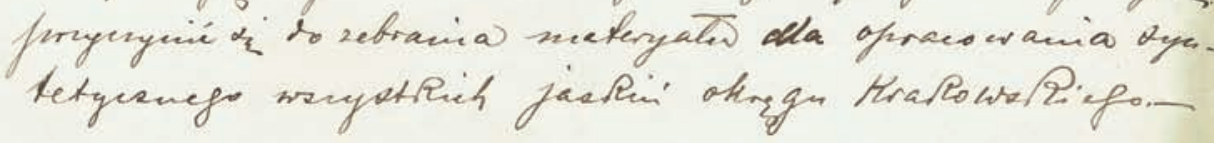

Ryc. 2. L. Kozłowski, rękopis opracowania zabytków z Jaskini Bębłowskiej ze zbiorów Muzeum Archeologicznego Akademii Umiejętności. Fot. ze zbiorów Muzeum Archeologicznego w Krakowie, Archiwum

Fig. 2. Leon Kozłowski, analysis of finds from the Bębło Cave in the collection of the Archaeological Museum of the Academy of Arts and Sciences; manuscript. Photo from the collection of the Archaeological Museum in Kraków, Archives 
Jako student Leon Kozłowski starał się również o pozyskanie do zbiorów Muzeum Akademii Umiejętności w Krakowie materiałów, które nie pochodziły z badań finansowanych przez tę instytucję. W $1911 \mathrm{r}$. wyjechał za granicę, do Kazimierzy Wielkiej, w dawnym powiecie pińczowskim (obecnie pow. loco), w sprawie wyposażenia słynnego grobu huńskiego, odkrytego w pobliskich Jakuszowicach. Jednak niedługo przed jego przybyciem zabytki te zostały ofiarowane jako depozyt do Muzeum Narodowego w Krakowie. Kozłowski usiłował nakłonić znalazców do wycofania depozytu i przekazania zabytków do Akademii Umiejętności, ale bezskutecznie (kartka pocztowa L. K. do W. Demetrykiewicza, 14 X 1911 r., teczka stanowiska Jakuszowice, pow. Kazimierza Wielka, MAK; ryc. 6). Inwentarz grobowy pozostał w Muzeum Narodowym i dopiero w 1938 roku został oddany do zbiorów Akademii (Sprawozdanie 1939, 49). Leon Kozłowski przekazywał także materiały z własnych odkryć. W 1912 roku ofiarował popielnicę,

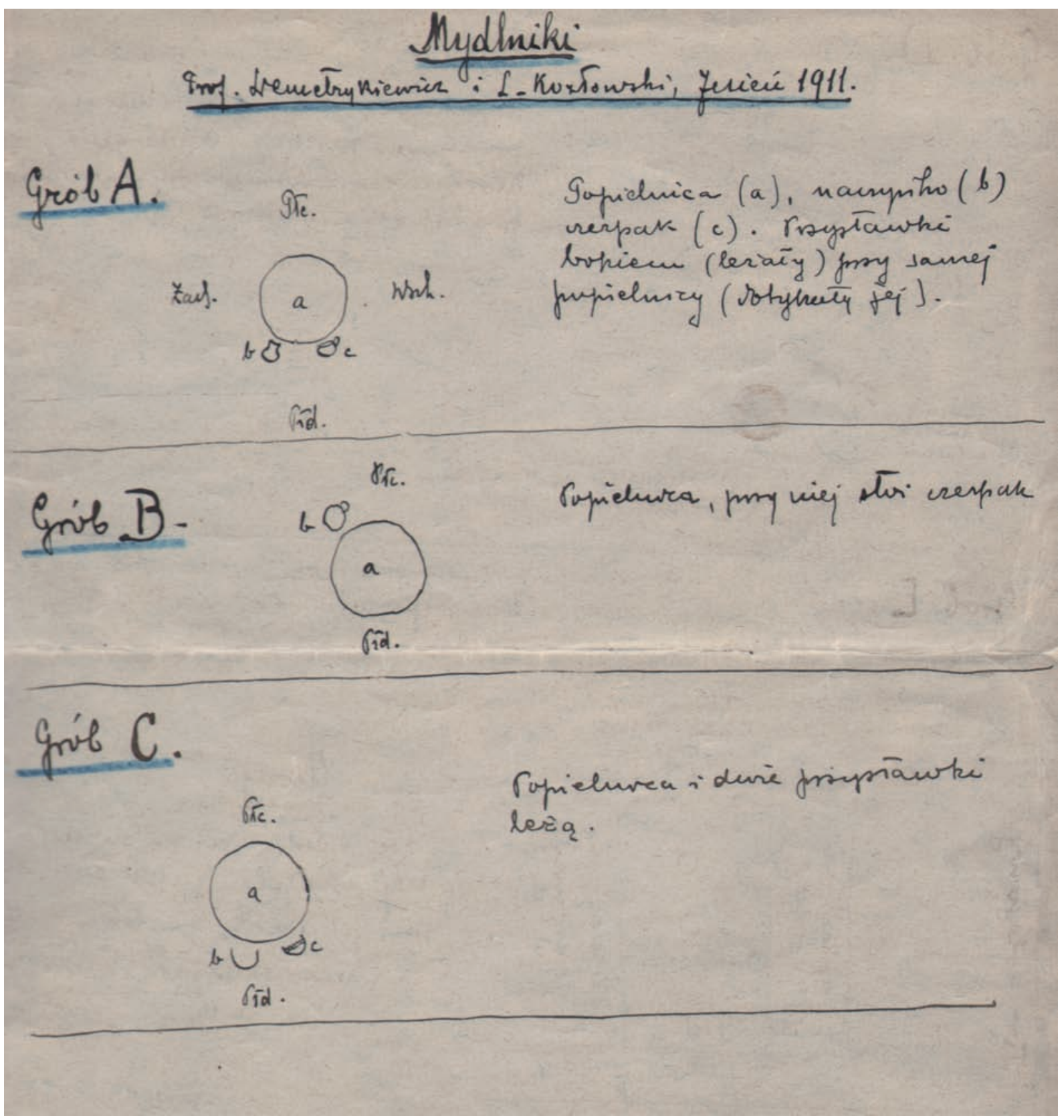

Ryc. 3. Dokumentacja wykonana przez L. Kozłowskiego podczas wykopalisk W. Demetrykiewicza w Mydlnikach, 1911 r., Muzeum Archeologiczne w Krakowie, Archiwum, teczka stanowiska Mydlniki, pow. Kraków

Fig. 3. Documentation prepared by Leon Kozłowski during the excavation carried out by Włodzimierz Demetrykiewicz in Mydlniki in 1911. The Archaeological Museum in Kraków, Archives, Mydlniki (Kraków district) folder 


\section{Cmentarzysko ciatopalne worrycack. 6}

Gro'b I. Iopiehica bes prystawek.

Grób II. Gopielnica bess prxystawen, zaurerajgea mato kosici.

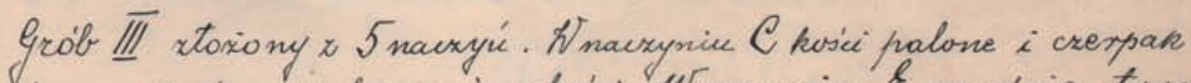
dnem dogóny mxyhrywajory hisic: Wnarynic \& na dice troche hisi praykrityeh dwo ma crespakami, jeden na drugieu.

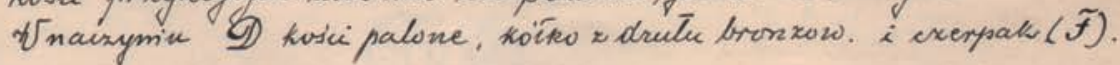

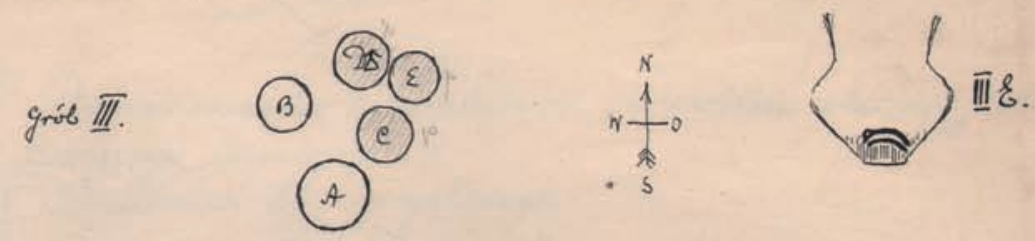

GroblV. xüviony 3 nawxyri: A popielnica, Bi $C$ prystuwte:

$$
\text { grib IV. (A) (C) } \frac{1}{3}
$$

- Grób V. Ono propielnicy * koviémi, xrujinowane.

Grób IV. Soprielnica ber prisystawek.

Gról VII. zrujnowany, ztozony jak sis xdaje a diou nacxyí :

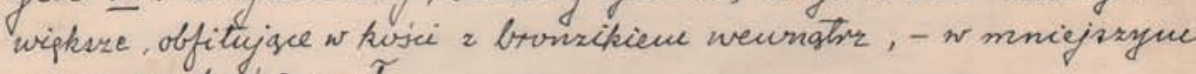
nacyniu kusici mato.

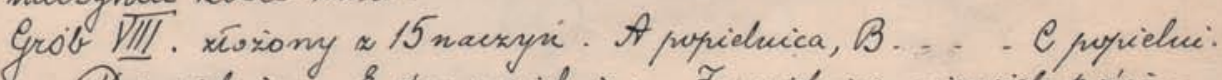
ca, Ppopieluica, \& dnopopiehicy. I pupielwica, nienriele kusici

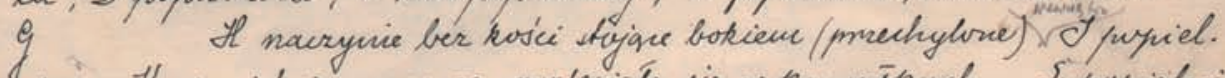

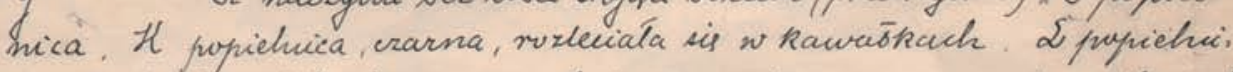
ca, weningtri kotho bronsowe, oboh noiyh kmencienny, kojici ile thals. ne. M crerpak stojgey bohiene, dotykat narrynia \&, - wicjscer za.

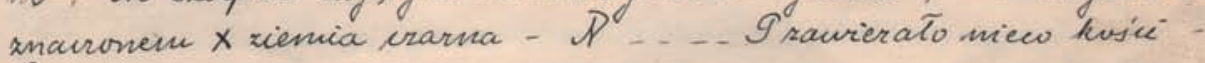
R...

Give $\sqrt{111}$.
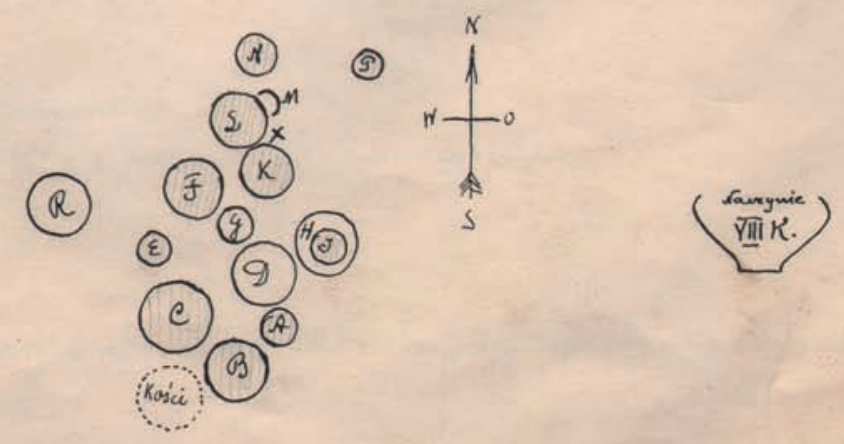

Ryc. 4. Sprawozdanie M. Drewki z badań w Gorzycach, 1912 r., Muzeum Archeologiczne w Krakowie, Archiwum, teczka stanowiska Gorzyce, pow. Tarnobrzeg

Fig. 4. Michał Drewko's report on exploration in Gorzyce, 1912. The Archaeological Museum in Kraków, Archives, Gorzyce (Tarnobrzeg district) folder 


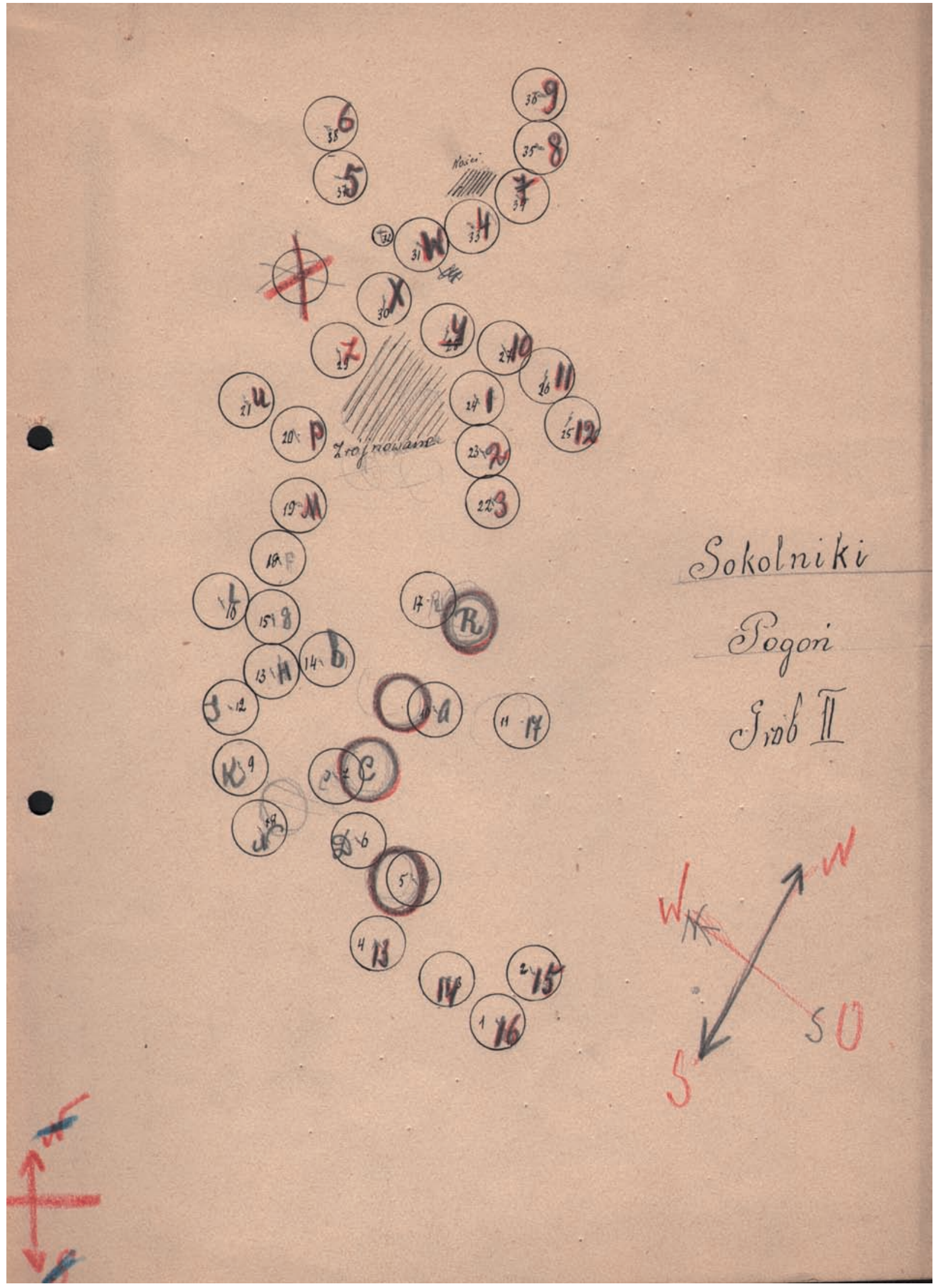

Ryc. 5. Plan stanowiska w Sokolnikach, pow. Tarnobrzeg. 1912 r., Muzeum Archeologiczne w Krakowie, Archiwum, teczka stanowiska Sokolniki, pow. Tarnobrzeg

Fig. 5. A map of the site in Sokolniki, Tarnobrzeg district, 1912. The Archaeological Museum in Kraków, Archives, Sokolniki (Tarnobrzeg district) folder 


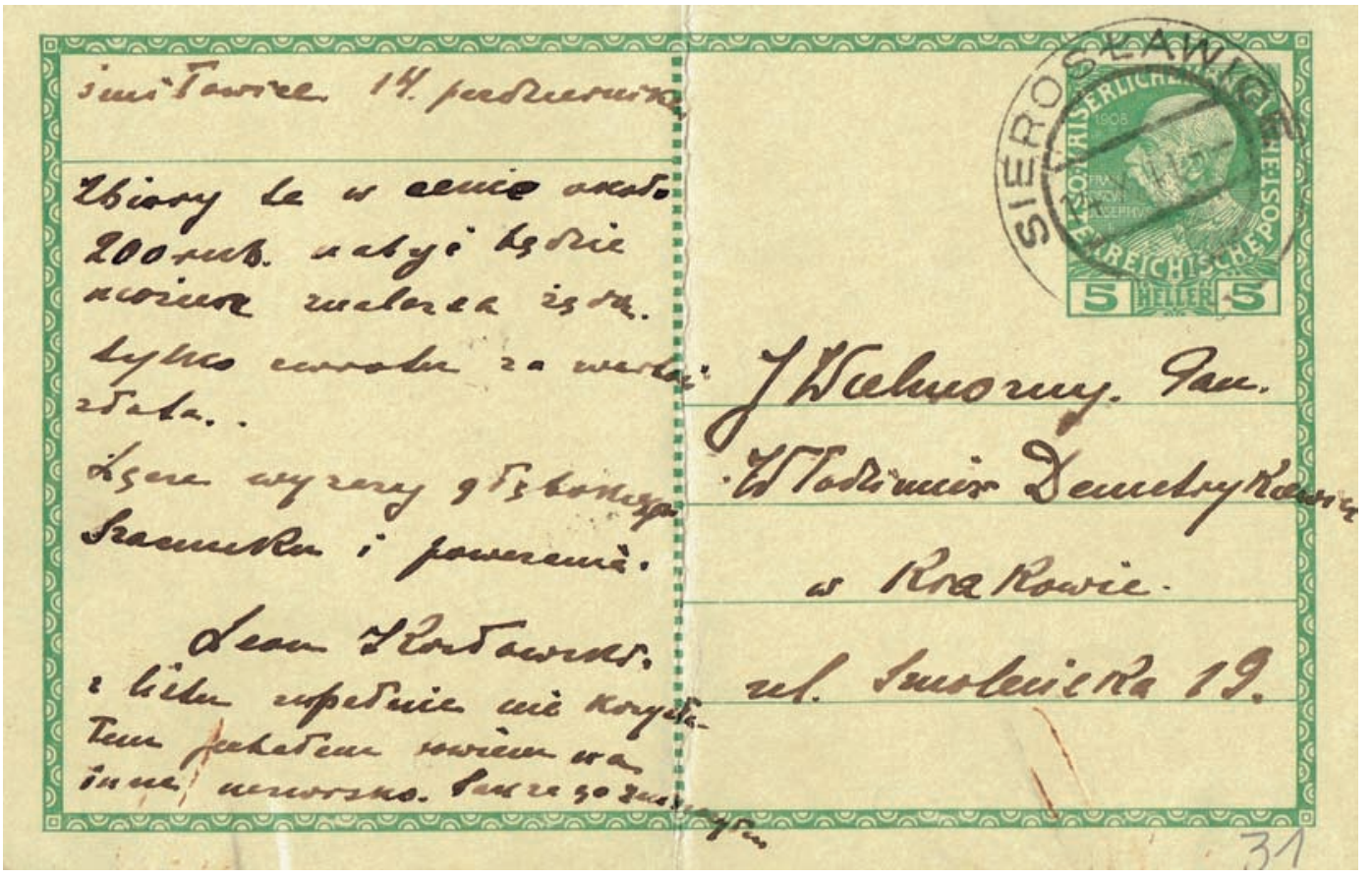

Ryc. 6. Kartka pocztowa L. Kozłowskiego do W. Demetrykiewicza z informacjami o znaleziskach z Jakuszowic. 1911 r. Muzeum Archeologiczne w Krakowie, Archiwum, teczka stanowiska Jakuszowice, pow. Kazimierza Wielka Fig. 6. A postcard Leon Kozłowski sent to Włodzimierz Demetrykiewicz with information about finds from Jakuszowice in 1911. The Archaeological Museum in Kraków, Archives, Jakuszowice (Kazimierza Wielka district) folder

dwa naczynia z brązu i żelazne umbo z grobu ciałopalnego z okresu rzymskiego z Pogwizdowa, w pow. miechowskim (ryc. 7), a także fragmenty fibul i dwie monety znalezione przypadkiem w Kazimierzy Wielkiej (Sprawozdanie 1913, 119-120; Sprawozdaniazposiedzeń 1914, XVIII-XIX).

Wykopaliska w Gorzycach i Sokolnikach nie były jedynymi badaniami, jakie młody archeolog prowadził z ramienia Akademii Umiejętności w ciągu dwóch pierwszych lat pobytu w Krakowie. W 1912 roku, przebywając w Jaksicach, w dawnym pow. miechowskim (ob. pow. Proszowice), Kozłowski natrafił na paleolityczne palenisko odsłonięte $\mathrm{w}$ lessowym urwisku nad brzegiem Wisły (Kozłowski, Kuźniar 1914). Kozłowskiemu i geologowi Wiktorowi Kuźniarowi (1879-1935) udało się pozyskać z Akademii fundusze na badania ratownicze. Po przybyciu na miejsce okazało się jednak, że część stanowiska uległa już całkowitemu zniszczeniu. Kuźniar pisał:

„Palenisko, które widniało w stromej ścianie lessowej nad brzegiem Wisły, mogło w każdej chwili zniknąć, tak samo jak zostało odsłonięte, albowiem brzeg w tym miejscu obrywa się ciągle. Przybywszy na miejsce zastaliśmy niestety tylko resztki, in situ; całość już przed naszym przybyciem wypadła razem z obsuniętym już poprzednio lessem do dzikiej strugi podeszczowej, a razem z nią do Wisły” (Kozłowski, Kuźniar 1914, 3).

Na zachowanej części stanowiska pozostało niewiele do przebadania. Kozłowski informował Demetrykiewicza:

„Po wyjeździe p[ana] Kuźniara odkopałem więc tylko od strony parowu palenisko. (...) Dokopałem się do żółtego zupełnie lessu. Na niewielkiej tylko przestrzeni pozostały się jeszcze węgle i popiół, nie sięgają one jednak dalej, jak 20-30 cm" (list L. K. do W. Demetrykiewicza, [1912 r.], MAK, sygn. SP8/36).

W artykule ${ }^{6}$ zamieszczonym w Materiałach Antropologiczno-Archeologicznych i Etnograficznych Kozłowski pisał, że na miejscu znalazł jedynie trzynaście wyrobów krzemiennych i kilka kości „łupanych i piłowanych, bez żadnych jednak cech wyrobu artystycznego" (Kozłowski, Kuźniar 1914, 7-9). Leon Kozłowski, który obok Włodzimierza Demetrykiewicza i Józefa Kostrzewskiego jako jeden z pierwszych

6 Artykuł ten był pierwszą z dwóch prac Leona Kozłowskiego opublikowanych w wydawnictwach Akademii Umiejętności. 


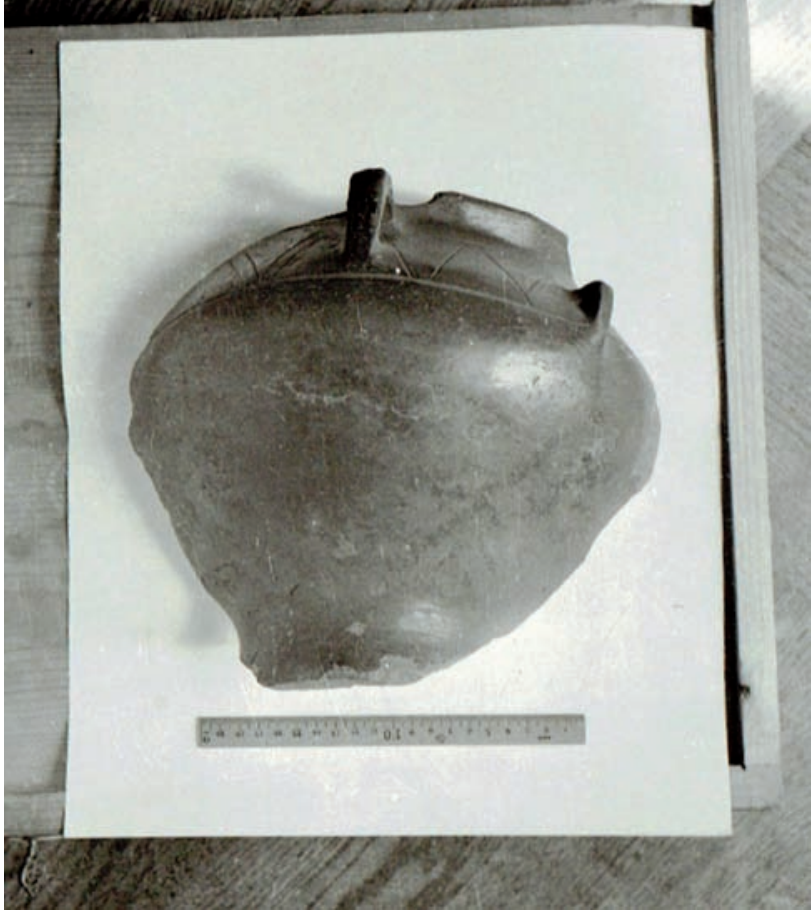

Ryc. 7. Fragment naczynia z Pogwizdowa, pow. Miechów, ofiarowany przez L. Kozłowskiego do zbiorów Muzeum Archeologicznego AU.

Fot. L. Kozłowski lub W. Demetrykiewicz. 1912 r. Muzeum Archeologiczne w Krakowie, Archiwum, teczka stanowiska Pogwizdów, pow. Miechów Fig. 7. A fragment of a vessel from Pogwizdów, Miechów district, given by Leon Kozłowski to the collection of the Archaeological Museum of the Academy of Arts and Sciences. Photo by L. Kozłowski or W. Demetrykiewicz, 1912. The Archaeological

Museum in Kraków, Archives, Pogwidów (Miechów district) folder

wprowadził do polskiej archeologii prehistorycznej pojęcie kultury archeologicznej i użył go już w 1913 roku, w pracy o Jaksicach nadal jednak pisał o okresach pradziejowych (Kozłowski, Kuźniar 1914, 9; Lech 1997-1998,48;2000,162-164; Woźny2018, 185). Przebadane w tej miejscowości stanowisko początkowo uważał za magdaleńskie (list L. K. do W. Demetrykiewicza, [1912 r.], MAK, sygn. SP8/36), później jednak datował je na okres oryniacki (Kozłowski, Kuźniar 1914, 9).

Przez cały okres pobytu w Krakowie Leon Kozłowski pozostawał w stałym kontakcie z Erazmem Majewskim, z którym współpracował aż do 1919 roku. Dzięki swojemu warszawskiemu mistrzowi w 1911 roku referował na posiedzeniu Towarzystwa Naukowego Warszawskiego wyniki badań powierzchniowych z okolic Jury Ojcowskiej (Kozłowski 1911a; 1911b). W tym samym roku rozpoczął również, finansowane przez redakcję należącego do Majewskiego Światowita, wykopaliska na górze Klin i na górze Babiej w Iwanowicach, w pow. miechowskim (obecnie pow. Kraków), które były kontynuowane także w następnych latach. Z ramienia redakcji Światowita prowadził badania grodziska na Sokolej Skale w Dolinie Będkowskiej na terenie Jury Ojcowskiej, a także poszukiwania archeologiczne w Wąchocku (Życiorys L. K., 1917 r., Teczka doktorska, Archiwum UJ, sygn. WF II 504; Kozłowski 1912; 1913a; 1913b; 1917; por. Lech 2001, 136; Lech, Piotrowska 2006, 163-166; Kaczorowski 2010, 409-412; Kozłowski 2010, 235-236).

\section{STUDIA W TYBINDZE. ROK 1912/1913}

Na przełomie 1912 i 1913 roku Leon Kozłowski przez kilka miesięcy przebywał w Tybindze, studiując u poznanego w 1912 roku w Krakowie specjalisty z dziedziny paleolitu, docenta Roberta Rudolfa Schmidta (1882-1950) ${ }^{7}$ (Jażdżewski, Jędruszczak 1970, 19; M. Kozłowski 2005, 25-26; Lech, Piotrowska 2006, 166-167). Obok wykładów z prehistorii (poznawał tam przede wszystkim zagadnienia paleolitu i neolitu), Kozłowski uczęszczał także na zajęcia z geologii, antropologii, chemii, fizyki, zoologii, anatomii, filozofii i historii średniowiecznej (Teczka habilitacyjna L. K., Archiwum UJ, sygn. WF II 121). W listach wysyłanych do Krakowa pisał, że przedmiotem, który zajmował go w szczególny sposób, była geologia. Na początku 1913 roku relacjonowat:

„Obecnie pracuję nad geologią, chcę bowiem posiąść w tym zakresie dostateczne wiadomości, jeżeli nie do prac oryginalnych, to przynajmniej by móc kontrolować naszych geologów w ich sądach archeologię przedhistoryczną obchodzących. Dochodzę już do pewnej jasności poglądu na zmiany fauny, a przede wszystkim w sprawie gryzoni, uczę się też samemu określać poszczególne gatunki, choć to praca bardzo trudna i musiałbym na to co najmniej jeden semestr poświęcić, by się nauczyć określać faunę dyluwialną" (list L. K. do W. Demetrykiewicza, 8 I 1913 r., MAK, sygn. SP8/36).

W. Demetrykiewicz pisał: „P[an] Leon Kozłowski wytrwa zdaje się przy archeologii. W lipcu zeszłego roku poznał się bliżej z prof. Schmidtem z Tybingi, który studiował w Krakowie nasze zabytki paleolitu przez 2 tygodnie i wybrał się na zimowe półrocze do Tybingi, aby wyspecjalizować się w paleolicie" (list W. Demetrykiewicza do J. Kostrzewskiego, 27 IV 1913 r., MAK, sygn. SP8/36). 
Podczas pobytu w Tybindze młody archeolog otrzymał korektę napisanej wspólnie z Wiktorem Kuźniarem pracy o badaniach na stanowisku w Jaksicach. Informując Demetrykiewicza o nanoszonych poprawkach, nie ukrywał entuzjazmu dla zdobywanej przez siebie wiedzy:

„Otrzymałem dziś korektę pracy o Jaksicach, zrobiłem daleko idące zmiany, a to pod wpływem studiów odbytych. Datowałem siedzibę i wyciągnąłem bardzo poważne wnioski. Trochę przy tym obtarłem nosa geologom. Ciekawy jestem co Kuźniar powie. Jeżeli ma ostatnią literaturę (...) to rację mi przyzna, przypuszczam jednak, że będzie trochę zły że (...) archeologowie więcej mogą mówić o dyluwianum niż geologowie, którym się zdaje, że dyluwianum to jest coś jak monopol tytuniowy, a fauna jedyną dla niego datą, a już szczególnie ten (...) Elephas primigenius, którego można znaleźć przez całe młodsze dyluwianum" (tamże).

Studiując w Niemczech Leon Kozłowski nadal pozostawał w bliskim kontakcie z krakowskimi archeologami, wymieniając częste listy z Włodzimierzem Demetrykiewiczem i Michałem Drewką. Już w październiku 1912 roku, kilka dni po przyjeździe do Tybingi, pisał do krakowskiego profesora o swoich pierwszych wrażeniach, perspektywach naukowego rozwoju, planach prac i podróży (list L. K. do W. Demetrykiewicza, 10 X 1912 r., tamże). Później zdawał także relacje $\mathrm{z}$ postępów $\mathrm{w}$ nauce, opisywał zwiedzane muzea (w Tybindze, Monachium, Zurychu, Wiedniu) $\mathrm{i}$ informował o oglądanych w nich zbiorach zabytków (listy L. K. do W. Demetrykiewicza, 10 X, 15 XII 1912 r.; 8 I, 13 IV 1913 r., tamże). W kwietniu 1913 roku, niedługo przed powrotem, obiecywał, że będąc już w Krakowie zda szczegółowe sprawozdanie $\mathrm{z}$ tego, co widział (list L. K. do W. Demetrykiewicza, 13 IV 1913 r., tamże). Dzięki korespondencji z Demetrykiewiczem i Drewką Kozłowski był także dobrze zorientowany w sprawach krakowskich. W 1912 roku komentował przyznanie większej subwencji na działalność Komisji Antropologicznej AU (list L. K. do W. Demetrykiewicza, 23 XII 1912 r., tamże). W jednym z listów odniósł się także krótko do nieporozumień pomiędzy Włodzimierzem Demetrykiewiczem i Karolem Hadaczkiem (1873-1914), profesorem archeologii klasycznej i prehistorii na Uniwersytecie Lwowskim (tamże). Kozłowski pisał także z Tybingi o poglądach R. R. Schmidta na oglądane przez niego w Krakowie znaleziska z Jaskini Okiennik w Skarżycach, w powiecie zawierciańskim (list L. K. do
W. Demetrykiewicza, 15 XII 1912 r., tamże). W sprawie materiałów z tej jaskini kontaktował się również z Wiktorem Kuźniarem, prosząc go o informacje na temat odkrytych tam szczątków zwierzęcych, na podstawie których sam zamierzał precyzyjniej określić chronologię stanowiska (tamże).

W Tybindze, obok studiów, Kozłowski zajmował się także opracowywaniem potrzebnych Schmidtowi materiałów wykopaliskowych $\mathrm{z}$ terenów wschodniej Europy. O tym, że wywarł na swoim nauczycielu bardzo korzystne wrażenie, świadczy fakt, że w 1913 roku Schmidt wnioskował o przyjęcie go do grona członków Berlińskiego Towarzystwa Antropologicznego oraz do założonego przez Gustawa Kossinnę (1858-1931) Niemieckiego Towarzystwa Prehistorycznego (list L. K. do W. Demetrykiewicza, 13 IV 1913 r., tamże). Schmidt proponował także swojemu uczniowi udział w podróżach naukowych. Już w grudniu 1912 roku Kozłowski wspominał Demetrykiewiczowi o pierwszych projektach wspólnych wypraw. Pisał:

„Szmidt zaś wyjeżdża w podróż do Północnej Afryki, proponuje mi, abym jechał razem z nim, mamy dokonać w Tunisie całego szeregu badań, zwiedzić wszystkie tamtejsze zabytki, a następnie zamierzam jechać do Hiszpanii w celu poznania malowideł paleolitycznych, do Paryża, Brukseli, Liège, Meitz? [Metz(?), Mainz(?) - pytajnik wtekście zostat postawiony przez Leona Kozłowskiego - przyp. aut.] i Berlin[a], gdyby podróż doszła do skutku zwiedziłbym wszystkie paleolity zachodnioeuropejskie i przywiózł ze sobą zbiór paleolitu Północno Afrykańskiego i może coś zachodniej Europy" (list L. K. do W. Demetrykiewicza, 15 XII 1912 r., tamże).

Na podróż tę jednak trzeba było wyłożyć znaczną kwotę pieniędzy. Kozłowski, który nie dysponował wystarczającymi środkami, zwrócił się do Włodzimierza Demetrykiewicza z pytaniem o możliwość uzyskania na ten cel stypendium lub długoterminowej pożyczki ${ }^{8}$ (tamże). Profesor, życzliwie przyglądający się naukowemu rozwojowi swojego ucznia, zareagował na jego prośbę bardzo szybko. Już w następnym tygodniu przez Michała Drewkę poinformował

8 Z podobną prośbą L. Kozłowski wystąpił także do E. Majewskiego, pytając go o możliwość uzyskania dotacji z Kasy im. Mianowskiego. Jednakże, poza jednym listem, sprawy tej w korespondencji z E. Majewskim więcej nie poruszał (list L. K. do E. Majewskiego, 13 XII 1912 r., Teka XV korespondencji E. Majewskiego, PMA). 
Kozłowskiego o możliwości otrzymania pożyczki z Akademii Umiejętności, w wysokości pięciuset koron (list L. K. do W. Demetrykiewicza, 23 XII 1912 r., MAK, sygn. SP8/36). Uzyskanie stypendium w tak krótkim czasie było w Akademii niemożliwe. $\mathrm{Z}$ czasem okazało się jednak, że plany wyjazdu do Tunisu nie mogły zostać zrealizowane. Schmidtowi nie udało się pozyskać potrzebnych funduszy, wobec czego zamierzał wyjechać do Francji, na mniej kosztowne badania w Dordonii, w rejonie Akwitanii. Kozłowski pisał do Demetrykiewicza:

„Nie jestem pewien, czy projekt dojdzie do skutku, bo przecież gdyby doszedł, te roboty, z punktu widzenia korzyści naukowej dla mnie, byłyby jeszcze ważniejsze i oczywiście pragnąłbym bardzo wziąć w nich udział. Gdy projekt będzie pewnym, a ja obliczę koszta, doniosę. Sądzę, że koszta będą mniejsze jak podróży do Tunisu" (tamże).

Ostatecznie jednak także tego wyjazdu nie udało się zrealizować. Natomiast opuszczając Tybingę Kozłowski po raz pierwszy wspomniał Demetrykiewiczowi o planach podróży do Rosji. Jedynej, na którą, jak pokazał czas, badaczom udało się wspólnie wyprawić. Podróż ta miała zostać sfinansowana przez jedno z rosyjskich ministerstw, a jej wyniki zamierzano opublikować w językach rosyjskim i niemieckim. Jednak wiosną 1913 roku Kozłowski jeszcze wątpił, by mogła ona dojść do skutku (list L. K. do W. Demetrykiewicza, 13 IV 1913 r., tamże).

\section{PO POWROCIE Z TYBINGI. BADANIA GROBOWCÓW KUJAWSKICH}

W początkach 1913 roku, przebywając jeszcze poza granicami kraju, Leon Kozłowski otrzymał od profesora Demetrykiewicza propozycję przeprowadzenia badań neolitycznych grobowców kujawskich. O pochówkach tych, zagrożonych zniszczeniem, powiadomił Włodzimierza Demetrykiewicza kanonik, a zarazem profesor historii sztuki we włocławskim seminarium duchownym, ks. Władysław Górzyński (1856-1920) (Kozłowski 1921, 1,6). Demetrykiewicz, który ze względów zdrowotnych nie chciał wybierać się w tak daleką podróż, postanowił umożliwić pochodzącemu z Królestwa Polskiego Leonowi Kozłowskiemu zbadanie tych obiektów (listy W. Demetrykiewicza do ks. W. Górzyńskiego, bruliony, II 1913 r.; 5, 18 i29 IV; 12 V 1913 r., MAK, sygn. SP8/36). Odpowiadając na list Michała Drewki, którym został powiadomiony o możliwości przeprowadzenia wykopalisk, Kozłowski pisał, że przyjmuje propozycję tym chętniej, że grobowce kujawskie, choć miały duże znaczenie dla nauki, nie były dobrze znane (list L. K. do W. Demetrykiewicza, 15 II 1913 r., tamże). Perspektywa prowadzenia wykopalisk wydawała się tym bardziej zachęcająca, że znał Włocławek, a na Kujawach, w powiatach rypińskim i lipnowskim mieszkała część jego rodziny (tamże).

Kozłowski nie chciał, by badaniami grobowców kujawskich zajęli się archeolodzy warszawscy. Nim jeszcze doszło do wykopalisk, pisał:

„Oddaniu zabytku w ręce pana Majewskiego i jego pomocników jestem bardzo przeciwny, nie tyle ze stanowiska patriotyzmu krakowskiego, ile że zabytek przy nieumiejętnym badaniu będzie zniszczony. Jest to bowiem jednym z najtrudniejszych do badania i sam mam pewne obawy czy z zadania dość dobrze się wywiążę"(tamże).

Wykopaliska na Kujawach - w Świerczynie, Rogalkach, Iłowie i Borucinie - Kozłowski prowadził wiosną 1913 roku (Sprawozdanie 1914, 57; Kozłowski 1921, 2-19). Opisywał je w listach do Demetrykiewicza. W maju, już pierwszego dnia po przybyciu na miejsce, na jednej z wydm znalazł zabytki pradziejowe. Wtedy też, w okolicach Dąbia, pow. Włocławek, natknął się na kopiec, który, po przeprowadzeniu badań („Rozkopałem go rowami 2 met[ry] szerokimi na krzyż, a środek szerzej rozebrałem”), określił jako związany z kulturą słowiańską ciałopalny kurhan grobowy (list L. K. do W. Demetrykiewicza, 24 V 1913 r., MAK, sygn. SP8/36). Ponieważ głównym celem jego pobytu na Kujawach było zbadanie neolitycznych grobowców megalitycznych, w późniejszym czasie pisał:

„Po przyjeździe na miejsce zadaniem moim stało się odszukanie możliwie dobrze zachowanych grobów, oraz zbadanie możliwie różnorodnych rodzajów konstrukcji kamiennych, tworzących te groby. Grobów takich udało mi się odkryć sześć, dwa w Świerczynie, o których podał wiadomość do Akademii ks. Kanonik Górzyński, jeden w Iłowie, jeden w Rogalkach i dwa w Borucinie" (Kozłowski 1921, 3).

Wcześniej natomiast, w jednym z listów do Krakowa Kozłowski informował, że w okolicy Świerczyna znajdowało się siedem grobowców megalitycznych (ryc. 8). Zamierzał rozkopać je wszystkie, przy czym zbadanie dwóch zajęło mu tydzień (list L. K. do W.Demetrykiewicza, 1 VI 1913 r., MAK, sygn. SP8/36). Zawiadamiał profesora o rezultatach swoich prac: 


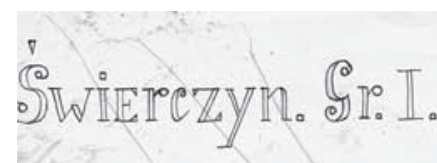

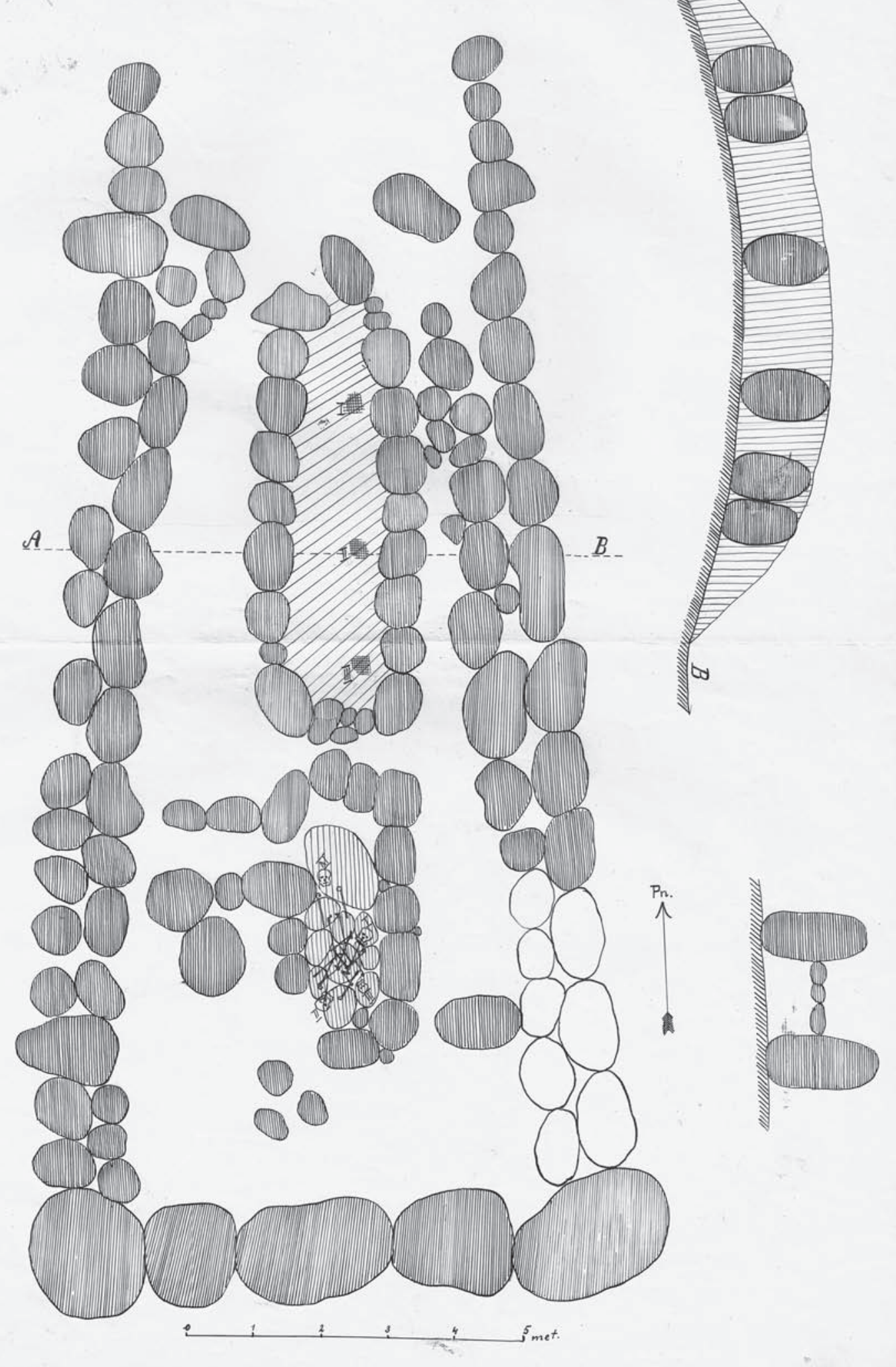

Ryc. 8. Plan grobowca megalitycznego w Świerczynie, pow. Radziejów Kujawski. Fot. za: Kozłowski 1921

Fig. 8. A plan of a megalithic grave in Świerczyn, Radziejów Kujawski district. Photo provided in Kozłowski 1921 
„Materiał kostny jest dobrym. Z ośmiu szkieletów dorosłych i dwóch dziecięcych tylko dwa duże i jeden dziecięcy nie zostały ocalone, inne wydobyto $\mathrm{w}$ dobrym stosunkowo stanie. Bardzo ciekawymi są budowle z kamieni, które się pokazały" (list L. K. do W. Demetrykiewicza, 1 VI 1913 r., tamże).

W innym miejscu pisał:

„W jednej [żali, czyli grobowcu megalitycznym przyp. aut.] odnalazłem skrzynię, w niej 4 szkielety, pokrytą kamieniami, a od niej aleję z ułożonych kamieni, cała żala otoczona jest dwoma rzędami kamieni. W drugiej również dwa rzędy kamieni okalających i aleja w środku, doprowadzająca do właściwego grobowiska. Na środku z osobnych kamieni ułożony krąg. Szkielety w liczbie pięciu w różnych głębokościach” (tamże).

Zdawał także relację $\mathrm{z}$ badań w Borucinie, pow. Radziejów Kujawski (Kozłowski 1921, 14-18):

„Dwie ostatnio rozkopane żale należą do nowego typu. Obstawienie boczne, to jest trójkąt zewnętrzny, prawie nieobecny, jedynie reprezentowana aleja, która cała służyła jako przestrzeń cmentarzyska właściwego. Praca w tych dwóch żalach była wyjątkowo ciężka ze względu na olbrzymie kamienie, które trzeba było poruszyć, przy czym trzeba się było uciec do pomocy lewara" (list L. K. do W. Demetrykiewicza, 15 VI 1913 r., MAK, sygn. SP8/36).

Kozłowski narzekał na trudności w pozyskaniu robotników i na złą pogodę (tamże). W czasie badań sporządzał plany badanych przez siebie obiektów. Zostały one później opublikowane w Materiałach Antropologiczno-Archeologicznych i Etnograficznych (Kozłowski 1921). W wysyłanych do Krakowa listach przedstawiał swoje pierwsze wnioski badawcze. Zauważał, że badane obiekty zarówno pod względem obrzędowym, jak i kulturowym były bardziej skomplikowane i niejednolite, niż sądzono wcześniej (list L. K. do W. Demetrykiewicza, 15 VI 1913 r., MAK, sygn. SP8/36). Na podstawie zmian zaobserwowanych w zbadanych obiektach sformułował hipotezę o stopniowym wygasaniu zwyczaju budowania tego typu pochówków, a także, ze względu na znalezienie pojedynczego naczynia kultury ceramiki wstęgowej, o istnieniu grupy niewolników, służących u pochodzącego z północy ludu twórców grobowców megalitycznych(Kozłowski 1921,12-13,17-18).WKrakowie, z wynikami badań Leona Kozłowskiego zapoznawał
Komisję Antropologiczną AU Włodzimierz Demetrykiewicz (Sprawozdania z posiedzeń 1919, X-XI).

Leon Kozłowski pozyskiwał materiały dla Akademii Umiejętności. Początkowo pisał, że muzealny rezultat badań był bardzo skąpy - główną ,zdobycz” stanowiło kilkanaście wisiorów bursztynowych. Kozłowski ubolewał, że nie natrafił na ani jedno całe naczynie lub na kamienne narzędzia (list L. K. do W. Demetrykiewicza, 1 VI 1913 r., MAK, sygn. SP8/36). Po zbadaniu kolejnych grobowców donosił, że z narzędzi krzemiennych natrafił na kilka wiórków, w jednym grobowcu znalazł sam szkielet, w innym trzy szkielety i skorupy naczyń (list L. K. do W. Demetrykiewicza, 7 VI 1913 r., tamże). Dopiero po badaniach w Borucinie informował o interesujących materiałach -

„znalazła się mianowicie ceramika sznurowa i ceramika półkulista pasowa, 8 kawałków bursztynu i 6 szkieletów, ale co dziwne, żaden nie całkowity, a kości porozrzucane bez porządku w alei” (list L. K. do W. Demetrykiewicza, 15 VI 1913 r., tamże).

Większość tych materiałów, przechowywanych później przez Kozłowskiego w jego majątku w Przybysławicach, w miechowskiem, uległa zniszczeniu w czasie Wielkiej Wojny (Kozłowski 1921, 3).

W trakcie pobytu na Kujawach Kozłowski starał się o powiększenie zbiorów muzealnych Akademii nie tylko drogą wykopalisk. Próbował także pozyskać zabytki od opiekuna zbiorów pradziejowych przechowywanych we włocławskim seminarium duchownym (list L. K. do W. Demetrykiewicza, 15 VI 1913 r., MAK, sygn. SP8/36). Zbierał także dla krakowskiego profesora różne informacje dotyczące archeologii. Pisał, że natrafił na ślady figur kamiennych, tzw. bab, którymi w tym czasie zajmował się Demetrykiewicz (list L. K. do W. Demetrykiewicza, 7 VI 1913 r., tamże). Wspominał o kamieniach z wyrytymi znakami i o figurach wydobytych z Gopła, których fotografie zamierzał przesłać do Krakowa (tamże).

\section{BADANIA W JASKINI MAMUTOWEJ}

W 1913 roku przed Leonem Kozłowskim otworzyła się możliwość przeprowadzenia z ramienia Akademii Umiejętności wykopalisk na terenie Jury Ojcowskiej, w Jaskini Mamutowej, znanej z wcześniejszych badań warszawskiego archeologa i właściciela Ojcowa, hr. Jana Zawiszy (1822-1887) (Kostrzewski 
1949, 74; Nosek 1967, 61-62; Lech 2001, 129-134). Badaniami w jaskiniach Jury zainteresowani byli zarówno Erazm Majewski (por. Lech, Piotrowska 2006, 165-172; Piotrowska 2006), jak i Włodzimierz Demetrykiewicz - dwaj ważni nauczyciele Kozłowskiego. Majewski, specjalizując się w paleolicie, nie posiadał w swoich zbiorach wielu materiałów pochodzących z tej epoki pradziejów. Jura Ojcowska była mu przy tym szczególnie bliska także dlatego, że stanowiła ulubione miejsce jego wakacyjnych pobytów (Modrzewska 1983/1987, 165; Lech 1996, 57). Natomiast Włodzimierz Demetrykiewicz opracowywał w tym czasie syntezę paleolitu w Polsce, wobec czego badania i materiały dotyczące tego regionu były dla niego szczególnie interesujące. Pomiędzy ośrodkami w Warszawie i Krakowie zaistniał konflikt interesów (Wrońska 1986, 133). Leon Kozłowski, któremu zależało na przeprowadzeniu niezwykle dla niego prestiżowych badań w Jaskini Mamutowej z ramienia Akademii Umiejętności, w tej niełatwej dla siebie sytuacji zdecydował się opowiedzieć po stronie Krakowa.

Leon Kozłowski i Włodzimierz Demetrykiewicz usiłowali początkowo zachować projekty wykopalisk w Jaskini Mamutowej w tajemnicy przed Erazmem Majewskim, jednakże wieści o planowanych badaniach szybko dotarły do warszawskiego prehistoryka. Kozłowski pisał:

„Wczoraj odebrałem list od Majewskiego, z którego wnoszę, że musiały się porobić pewne komplikacje w Tow[arzystwie] Naukowym. Nie wiem też, kto uwiadomił Majewskiego o kopaniach jaskiń, gdyż ja tylko mimochodem, i to z zastrzeżeniami, o projektach na lato mówiłem kładąc nacisk na badania w Iwanowicach" (list L. K. do W. Demetrykiewicza, 28 VII 1913 r., MAK, sygn. SP8/36).

Erazm Majewski usiłował odwieść Leona Kozłowskiego od podjęcia zamierzonych badań. Uważał, że brakowało mu niezbędnego doświadczenia, a niewielka liczba stanowisk jaskiniowych na terenach ziem polskich w szczególny sposób obligowała archeologów do prowadzenia wyłącznie w pełni fachowych wykopalisk. Pisał:

„Dowiedziałem się, że Sz[anowny] Pan ma rozkopywać groty - zapewne z wiedzą p[ana] Demetrykiewicza. Otóż ze względu na nieliczność grot w kraju - do tego należy moim zdaniem przystępować z wielkim zasobem wiedzy odnośnej - i ze względu na subtelność badań, nigdy samemu. Groty u nas, jak i za granicą - rozkopują doświadczeni archeol[odzy] - i najczęściej we dwóch, a nawet we trzech, aby jeden był kontrolerem drugiego, pomocnikiem i śsiadkiem. Wiem, że Sz[anowny] Pan nie przecenia swego doświadczenia prahistorycznego, więc tylko zwracam na to uwagę, że niezbędnym byłoby dobranie sobie kogoś drugiego, nie mówiąc już o tym, że trzeba by z góry ułożyć plan postępowania - aby nie wykonać pracy wadliwie i wszystkie możliwe ewentualności przewidzieć. Jako członek T[owarzyst]wa Naukowego proszę Pana również o wstrzymanie się w tym roku od takiej roboty, przynajmniej na terenie Królestwa Polskiego (co do Galicji - nie czuję się w prawie)" (list E. Majewskiego do L. K., 24 VII 1913 r., tamże).

Majewski pisał, że w wypadku podjęcia przez Kozłowskiego samodzielnych badań w Jaskini Mamutowej poruszyłby tę sprawę na posiedzeniu Warszawskiego Towarzystwa Naukowego. Zaznaczał jednocześnie, że nie zamierzał narzucać mu współpracy ze Stefanem Krukowskim. Pisał:

„Chodzi o kogoś poważniejszego - a kogo? Niech to prof. D[emetrykiewicz] obmyśli. Choćby kogoś z Czechów" (tamże).

Odpowiadając na ten list, Kozłowski nie do końca szczerze thumaczył swojemu mistrzowi, że nigdy nie zamierzał podejmować odpowiedzialności, jaką było prowadzenie samodzielnych wykopalisk na stanowiskach jaskiniowych. Informował, że planowanymi badaniami miała się zająć komisja składająca się z geologa, archeologa oraz, prawdopodobnie, także paleontologa. Pisał:

„Czy będę ze strony archeologicznej zaproszony, nie wiem, jest to tylko moim przypuszczeniem, że tak się stanie. W razie gdybym był powołany, obowiązek na siebie przyjmę" (list L. K. do E. Majewskiego, 27 VII 1913 r., tamże).

Dodawał, że do badań w jaskiniach zachęcał go docent R. R. Schmidt, na którego pomoc mógł liczyć, i podkreślał, że poza sobą nie znał żadnego zainteresowanego prehistoryka, który miałby „choćby skromne lecz fachowe przygotowanie” (tamże). Zaznaczał, że wstrzymanie badań nie leżało w jego kompetencjach i otwarcie pytał, czy list Majewskiego nie pozostawał w związku z planami przeprowadzenia przez Warszawskie Towarzystwo Naukowe własnych badań w jaskiniach ojcowskich. Prosząc o odpowiedź, pisał, że będzie od niej uzależniał dalsze postępowanie w tej sprawie. Majewskiego uspokoiła ta odpowiedź. 
Wyjaśniał, że jego list nie miał związku z planami Towarzystwa Naukowego i wyrażał przekonanie, że Kozłowski bez trudu znajdzie towarzysza badań wśród archeologów z Czech lub Moraw (list E. Majewskiego do L. K., 7 VIII 1913 r., tamże).

Leon Kozłowski o wszystkim informował Włodzimierza Demetrykiewicza. Przesyłając mu swoją korespondencję z Erazmem Majewskim, pisał:

„List ten załączam dla lepszego poinformowania p[ana] Profesora o całej sprawie, jak również moją odpowiedź o ewentualnej dalszej korespondencji zawiadomię, nie sądzę, aby sprawa przybrała szerszy rozmiar, jednak posyłam oba listy uważając to za swój obowiązek względem pana Profesora (...)" (list L. K. do W. Demetrykiewicza, 28 VII 1913 r., tamże).

Włączenie się Majewskiego w tę sprawę bardzo zaniepokoiło Kozłowskiego, który obawiał się, by jego interwencja nie przeszkodziła mu w realizacji planów naukowych. W liście do Demetrykiewicza pisał:

„Co do badań jaskiniowych, to sądzę, że należy je rozpocząć szybko, gdyż rosnące apetyta Warszawy mogą sprawę pokrzyżować ze szkodą Krakowa" (tamże).

Jednak perswazje Majewskiego nie odniosły zamierzonego skutku. Wprawdzie początkowo, po wymianie listów ze swoim mistrzem, Kozłowski nie chciał samodzielnie prowadzić wykopalisk w Jaskini Mamutowej i zamierzał zaprosić do nich również związanego z Komisją Antropologiczną AU geologa Wiktora Kuźniara, jednak ostatecznie badania te (sondaż) przeprowadził sam (tamże; Kozłowski 1922, 24). W okresie, kiedy młody archeolog przygotowywał się do badań w Jaskini Mamutowej, krystalizowały się także plany jego podróży z R. R. Schmidtem nad Morze Czarne. W jednym z listów do Demetrykiewicza wyrażał nadzieję, że zdobyte w czasie tej wyprawy doświadczenie pozwoli mu na prowadzenie badań na stanowiskach jaskiniowych w Polsce bez protestów ze strony Majewskiego lub innych archeologów. Pisał:

„Po tej podróży Warszawa będzie miała całkowicie zamknięte usta i ja będę miał całkowitą swobodę działania w polskich jaskiniach. Schmidt nie ma dotychczas żadnych w tym kierunku apetytów" (list L. K. do W. Demetrykiewicza, 1913 r., MAK, sygn. SP8/36).

Leon Kozłowski rozpoczął wykopaliska w Jaskini Mamutowej we wrześniu 1913 roku, jako wysłannik
Muzeum Akademii Umiejętności w Krakowię. Badania prowadził na tarasie znajdującym się przed jaskinią (Kozłowski 1922, 24-29; Lech 2001, 136; Lech, Piotrowska 2006, 171-172). W listach do Demetrykiewicza opisywał prowadzone przez siebie prace:

„Robota idzie bardzo powoli, gdyż mam do przezwyciężenia znaczne trudności. Zawisza wyrzucał całą ziemię z jaskini przed jaskinię, przysypując głazy z oberwanego sklepienia. Teren dotychczas nie kopany podzieliłem na dwie części: jedna od bramy w dół, druga od bramy ku nowemu wejściu do jaskini, a więc do terenu rozkopanego już przez Zawiszę. Rozpocząłem od rozkopywania części leżącej przed bramą. Po usunięciu wszystkiego, co wyrzucił Zawisza, odsłoniłem dawną powierzchnię i przystąpiłem do rozkopywania humusu, zmuszony byłem usuwać olbrzymie głazy używając klinów, a nawet dynamitu. Usuwanie wysypki, humusu i głazów zajęło mi całe 4 dni pracy i zaledwie zdoła[łe]m odkryć z wierzchu warstwę dyluwialną, z której również sterczą głazy. Warstwa ta poczynając od samej bramy biegnie ukośnie. Warstwowe więc zdejmowanie będzie bardzo utrudnione, nie będzie też można używać sznurów i powbijać prętów, gdyż wystające głazy na to nie pozwolą" (list L. K. do W. Demetrykiewicza, 1913 r., MAK, sygn. SP8/36).

9 W przygotowanym dla L. Kozłowskiego liście polecającym W. Demetrykiewicz pisał: „Muzeum wykopalisk przedhistorycznych Akademii Umiejętności w Krakowie wysyła W[ielmożnego] Pana Leona Kozłowskiego, kandydata archeologii i asystenta tegoż Muzeum, w celu naukowego badania jaskiń pod względem archeologicznym jako siedlisk człowieka epoki przedhistorycznej, jak niemniej w celu ewentualnego badania naukowego także innych zabytków archeologicznych, t.j. cmentarzysk lub jam mieszkalnych. P[an] Kozłowski jest również upoważniony przyjmować ofiarowane dla Muzeum Akademii dary oryginalnych wykopalisk, jak np. urny, narzędzia lub inne przybory wyrobione z kamienia, kości lub metalu itp. zabytki, które nieraz wychodzą na jaw w toku orki lub innych robót ziemnych, a przechowywane bez pożytku dla nauki w domach prywatnych pozbawione są tam często należytej opieki i narażone z czasem na uszkodzenie lub zniszczenie. Zarząd Muzeum archeologicznego Akademii Umiejętności wystawiając W[ielmożnemu] Panu Leonowi Kozłowskiemu niniejsze pismo polecające uprasza uprzejmie wszystkie $\mathrm{P}$ [leno] T[itulo] Osoby, którym sprawy badań i celów naukowych nie są obojętne, a przede wszystkim Przewielebne Duchowieństwo oraz Jaśnie Wielmożnych Panów Obywateli ziemskich, aby raczyli zadanie i pracę wysłannika Muzeum najwyższej naszej instytucji naukowej życzliwie popierać i możliwie ułatwiać. Kraków [pozostawiono puste miejsce na wpisanie dnia - przyp. aut.] września 1913" (W. Demetrykiewicz, brulion, 1913 r., MAK, sygn. SP8/21). 
Badacz przedstawiał także Demetrykiewiczowi „muzealne rezultaty” - Jan Zawisza pozostawił w usypanej ziemi liczne materiały - w warstwie humusu Kozłowski znalazł fragmenty naczyń i narzędzia neolityczne, natomiast w warstwie określonej przez siebie jako „dyluwialna”, natrafił na zwierzęce szczątki kostne („kosteczki gryzoni”) i artefakty, które wiązał z okresem magdaleńskim (tamże; Kozłowski 1922, 24). Na badanym przez siebie tarasie, pod usypiskiem i humusem, wyodrębnił warstwy, które przypisał epokom magdaleńskiej, solutrejskiej i mustierskiej (Kozłowski 1922, 25, 28-29). Z każdej z nich pobierał próbki, zamierzając odtworzyć w Muzeum Akademii cały profil badanej przez siebie jaskini (list L. K. do W. Demetrykiewicza, 1913 r., MAK, sygn. SP8/36).

\section{BADANIA PRZY KOPCU WANDY W MOGILE POD KRAKOWEM}

Obok samodzielnych badań prowadzonych z ramienia Akademii Umiejętności na Kujawach i w Jaskini Mamutowej, w 1913 roku Leon Kozłowski, wraz z Michałem Drewką, uczestniczył również w wykopaliskach neolitycznej osady we wsi Mogiła pod Krakowem (obecnie Kraków-Mogiła) przy Kopcu Wan- dy (Sprawozdanie 1914, 57). W Archiwum Muzeum Archeologicznego w Krakowie, w teczce stanowiska Kopiec Wandy-Kraków, zachowała się dokumentacja terenowa, sporządzona przez Leona Kozłowskiego w trakcie tych prac (ryc. 9, 10). Po wykopaliskach w Mydlnikach, były to drugie badania, w których młody adept prehistorii brał udział u boku profesora Demetrykiewicza.

\section{SPROWADZENIE DO AKADEMII ZBIORÓW HR. JANA ZAWISZY}

Studiując na Uniwersytecie Jagiellońskim i angażując się w prace Muzeum Archeologicznego Akademii Umiejętności, Leon Kozłowski, nawet w czasie swojego pobytu w Tybindze, wiązał swoją przyszłość z Krakowem. Zdarzało się, że nie bacząc na interesy warszawskiego ośrodka prehistorycznego, zogniskowanego wokół osoby jego mistrza, Erazma Majewskiego, dążył do powiększenia zbiorów Akademii Umiejętności. Jeszcze przed podjęciem badań w Jaskini Mamutowej myślał o sprowadzeniu z Warszawy do Muzeum Akademii zbiorów Jana hr. Zawiszy, w oparciu o które planował - w tym czasie - napisanie swojej rozprawy doktorskiej (notatka W. Demetrykie-

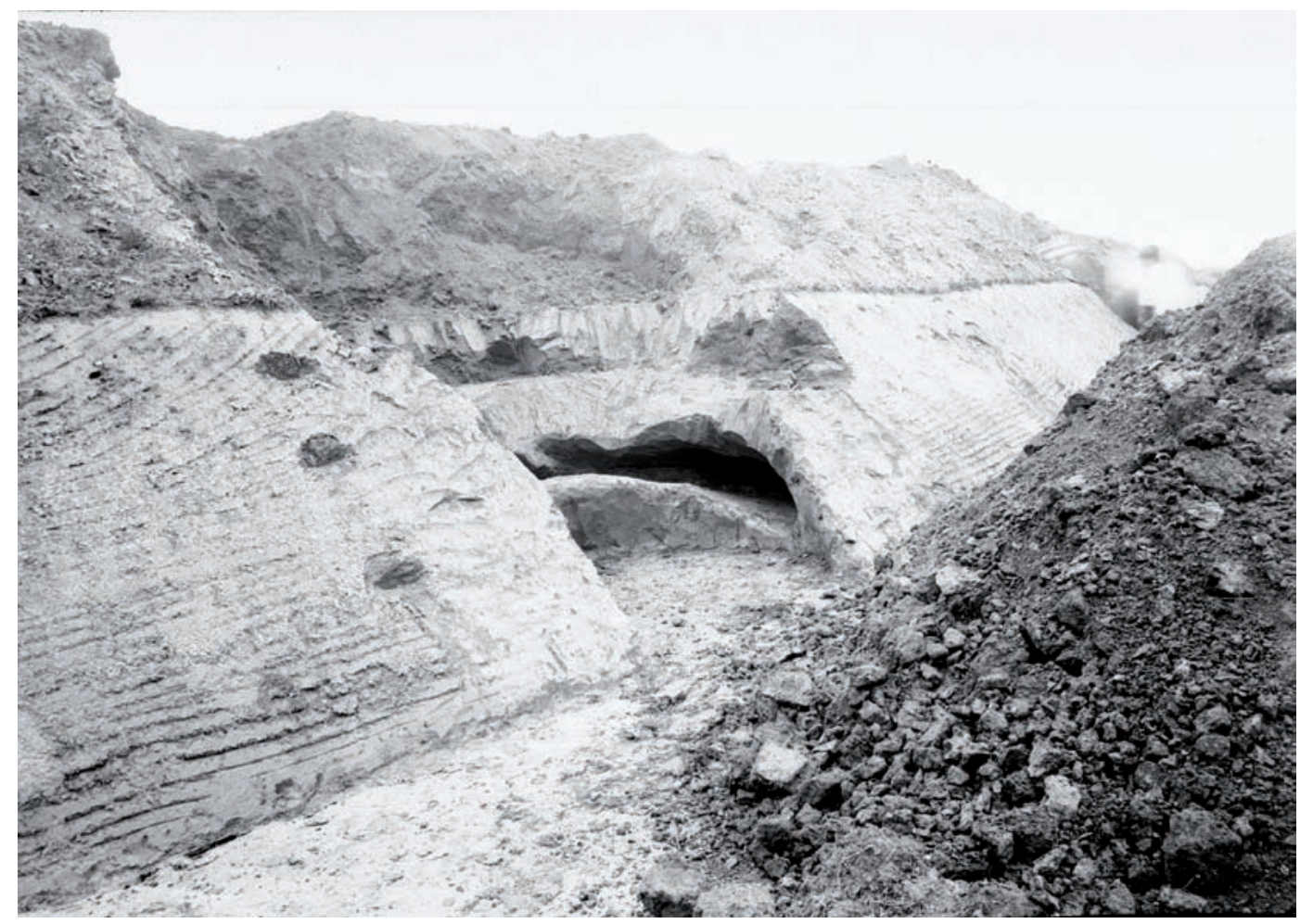

Ryc. 9. Badania w Mogile pod Krakowem. 1913 r. Muzeum Archeologiczne w Krakowie, Archiwum, Fot. Nr kat. 848

Fig. 9. Exploration in Mogiła near Kraków in 1913. The Archaeological Museum in Kraków, Archives, photo no 848 


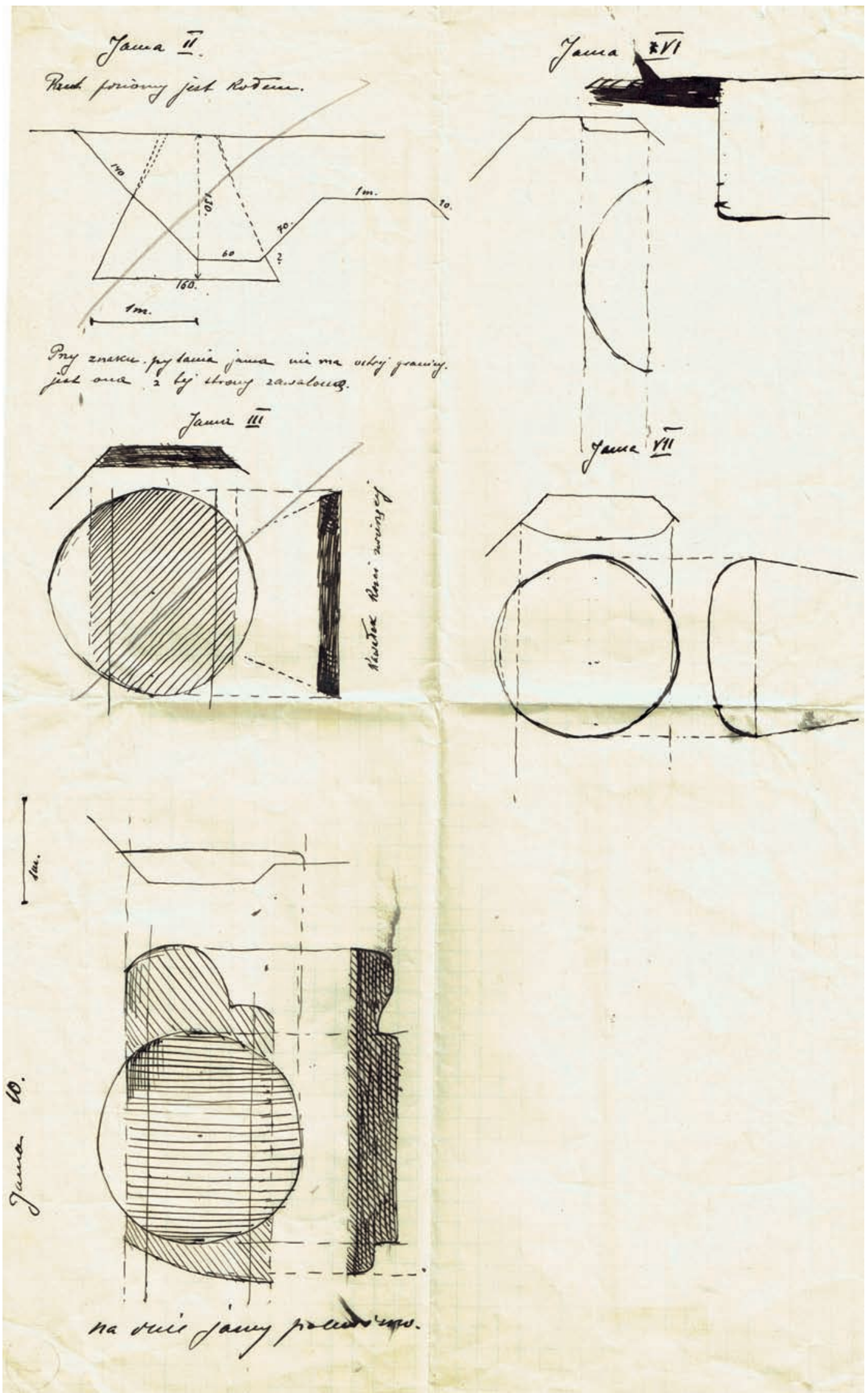

Ryc. 10. Dokumentacja wykonana przez L. Kozłowskiego podczas wykopalisk W. Demetrykiewicza w Mogile.

1913 r., Muzeum Archeologiczne w Krakowie, Archiwum, teczka stanowiska Kopiec Wandy

Fig. 10. Documentation prepared by Leon Kozłowski during Włodzimierz Demetrykiewicz’s excavation in Mogiła in 1913. The Archaeological Museum in Kraków, Archives, Wanda Mound folder 
wicza, brulion, 1922 r., MAK, sygn. SP8/23). Wybuch Wielkiej Wojny wraz ze wszystkimi jej konsekwencjami - między innymi także kilkuletnim wyjazdem Demetrykiewicza z Krakowa (por. Woźny 2018, 311$314,327-331$ ), a przede wszystkim wojennymi losami samego Kozłowskiego, stanął na przeszkodzie realizacji tych planów. Rozprawa doktorska Leona Kozłowskiego powstała $\mathrm{w}$ oparciu o zupełnie inne materiały i została obroniona na Uniwersytecie w Tybindze. W 1913 roku nikt jednak nie przewidywał jeszcze takiego rozwoju wydarzeń. Kozłowski pisał wtedy:

„Należałoby koniecznie pomyśleć o ściągnięciu wykopalisk Zawiszy do Krakowa, już dziś Kraków na Austrię posiada najlepsze zabytki, a tak przeskoczyłby nawet Tübingen. Najbliższym zaś zadaniem u nas w zakresie paleolitu jest stworzenie stratygrafii, co przy badaniach szybko można uskutecznić. Zająłby wówczas Kraków poczytne [poczesne? - przyp. aut.] miejsce w rzędzie muzeów paleolitycznych" (list L. K. do W. Demetrykiewicza, 15 II 1913 r., MAK, sygn. SP8/36).

W maju 1913 roku, jadąc na badania grobowców kujawskich, Kozłowski zatrzymał się w Warszawie, aby pozyskać bliższe informacje na temat zbiorów Jana Zawiszy znajdujących się w rękach księżnej Marii z Zawiszów Krasińskiej Radziwiłłowej10 (list L. K.

$10 \mathrm{~W}$ podjętych kilka miesięcy później staraniach o pozyskanie kolekcji, Leon Kozłowski miał oficjalne poparcie profesora Demetrykiewicza. W podpisanym przez kustosza Muzeum Archeologicznego Akademii liście polecającym zostało napisane: „Niniejszym pismem popieram usilnie prośbę p[ana] L[eona] Kozłowskiego uzyskania cennych wykopalisk archeologicznych po ś.p. p[anie] hr. Janie Zawiszy z jaskini Mamutowej, dla naukowego ich opracowania. (...) Pan Leon Kozłowski jest asystentem muzeum wykopalisk przy Akademii Umiejętności, odbył studia uniwersyteckie pod moim kierunkiem, a także przez podróże naukowe pogłębił je zagranicą. Specjalnością jego jest paleolit, tak że uważam go za najodpowiedniejszego z polskich badaczy na tym polu do opracowania wykopalisk z jaskini mamuta. Robił on również z ramienia Komisji antropologicznej dopełniające badania w tej jaskini, przez co ma do dyspozycji już pewien nowy materiał będący w posiadaniu Muzeum archeologicznego Akademii. Materiał ten jednak dopiero $\mathrm{w}$ łączności z cennymi zbiorami po ś.p. hr. Janie Zawiszy może być naukowo opracowany. Dokładność i sumienność opracowania jest w tym wypadku zapewnioną, a zabytki będą w rozprawie naukowej porównawczo zestawione $\mathrm{z}$ analogicznymi wykopaliskami z Niemiec i Francji i opracowane wedle najnowszych metod i zdobyczy na tym polu. Do opracowania niezbędnym jest dłuższe rozpatrzenie i analiza materiału wykopalisko- do W. Demetrykiewicza, 21 V 1913 r., MAK, sygn. SP8/36). W styczniu 1914 roku finalizował już pertraktacje - księżna zgodziła się na czasowe wypożyczenie kolekcji do Krakowa i jej ponowne opracowanie. Kozłowski pisał, że w prowadzonych rozmowach najważniejszą osobą był reprezentujący księżnę architekt Łukasz Wolski, warszawski patriota i bliski znajomy Erazma Majewskiego (list L. K. do W. Demetrykiewicza, 10 I 1914 r., MAK, sygn. SP8/36). Znajomość Wolskiego z warszawskim prehistorykiem czyniła sprawę szczególnie delikatną. Kozłowski prosił profesora Demetrykiewicza o pośpiech w przygotowaniu potrzebnych pism, ponieważ

„grozi (...), że do obejrzenia zbiorów będzie wezwany $\mathrm{p}$ [an] Majewski, co byłoby oczywiście trudnym momentem w akcji, teraz go nie ma w Warszawie, więc jest spokój” (list L. K. do W. Demetrykiewicza, 3 I 1914 r., tamże).

Ostatecznie sprawę udało się poprowadzić po myśli Leona Kozłowskiego i już w połowie stycznia kończono pakowanie zbiorów. Kozłowski, który wraz z Wolskim sporządził ich inwentarz, pisał wtedy:

„Wszystkich wyrobów krzemiennych jest z górą tysiąc, w tym większość wiórów. Wyrobów kościanych przeszło sześćdziesiąt. Spodziewałem się lepszego materiału, to jednak i to, co jest, jest bardzo ważne" (list L. K. do W. Demetrykiewicza, 10 I 1914 r., tamże).

Akademia zobowiązała się poddać zabytki konserwacji - szczególnie naglące było zabezpieczenie „wyrobów z kłów mamuta przed dalszym rozpadaniem" (notatka W. Demetrykiewicza, brulion, 1922 r., MAK, sygn. SP8/23). Ale głównym celem, a zarazem warunkiem wypożyczenia, było opracowanie kolekcji i opublikowanie monografii, w której zostałyby podkreślone naukowe zasługi Jana hr. Zawiszy. Na potrzeby tej publikacji księżna dostarczyła sześć wykonanych wcześniej tablic (tamże; ryc. 11). O przejęciu w depozyt zbiorów Zawiszy Włodzimierz Demetry-

wego, dlatego proszę o łaskawe udzielenie pozwolenia p[anu] Kozłowskiemu, żeby mógł te wykopaliska przewieźć na czas badań do Krakowa (...)" (projekt pisma adresowanego do ks. M. Radziwiłłowej, brulion, napisany ręką L. Kozłowskiego z poprawkami naniesionymi przez W. Demetrykiewicza, b.d. [1913 r.], MAK, sygn. SP8/23). Jednak ta tak pochlebna opinia o młodym badaczu nie została napisana przez kustosza Muzeum Akademii, ale przez samego Kozłowskiego. Podpisujący ją Demetrykiewicz naniósł na nią jedynie niewielkie poprawki. 
kiewicz powiadomił Komisję Antropologiczną Akademii Umiejętności w czerwcu 1914 roku (Sprawozdania z posiedzeń 1919, X). W 1922 roku kolekcja ta, dzięki jego staraniom, została zakupiona od księżnej Radziwiłłowej dla Akademii za pozyskaną od Ministerstwa Wyznań Religijnych i Oświecenia Publicznego kwotę miliona marek (Dokumentacja zakupu kolekcji J. hr. Zawiszy, MAK, sygn. SP8/23).
Leon Kozłowski nie zdążył rozpocząć opracowywania zbiorów przed wybuchem Wielkiej Wojny. Prace te zostały początkowo odłożone na, jak się wtedy wydawało, niedługi czas, ze względu na zorganizowany przez docenta R. R. Schmidta wspólny wyjazd naukowy na tereny położone nad wybrzeżem Morza Czarnego i na Kaukaz. Z wyprawy tej Kozłowski powrócił $\mathrm{w}$ przededniu wojny, myśląc już

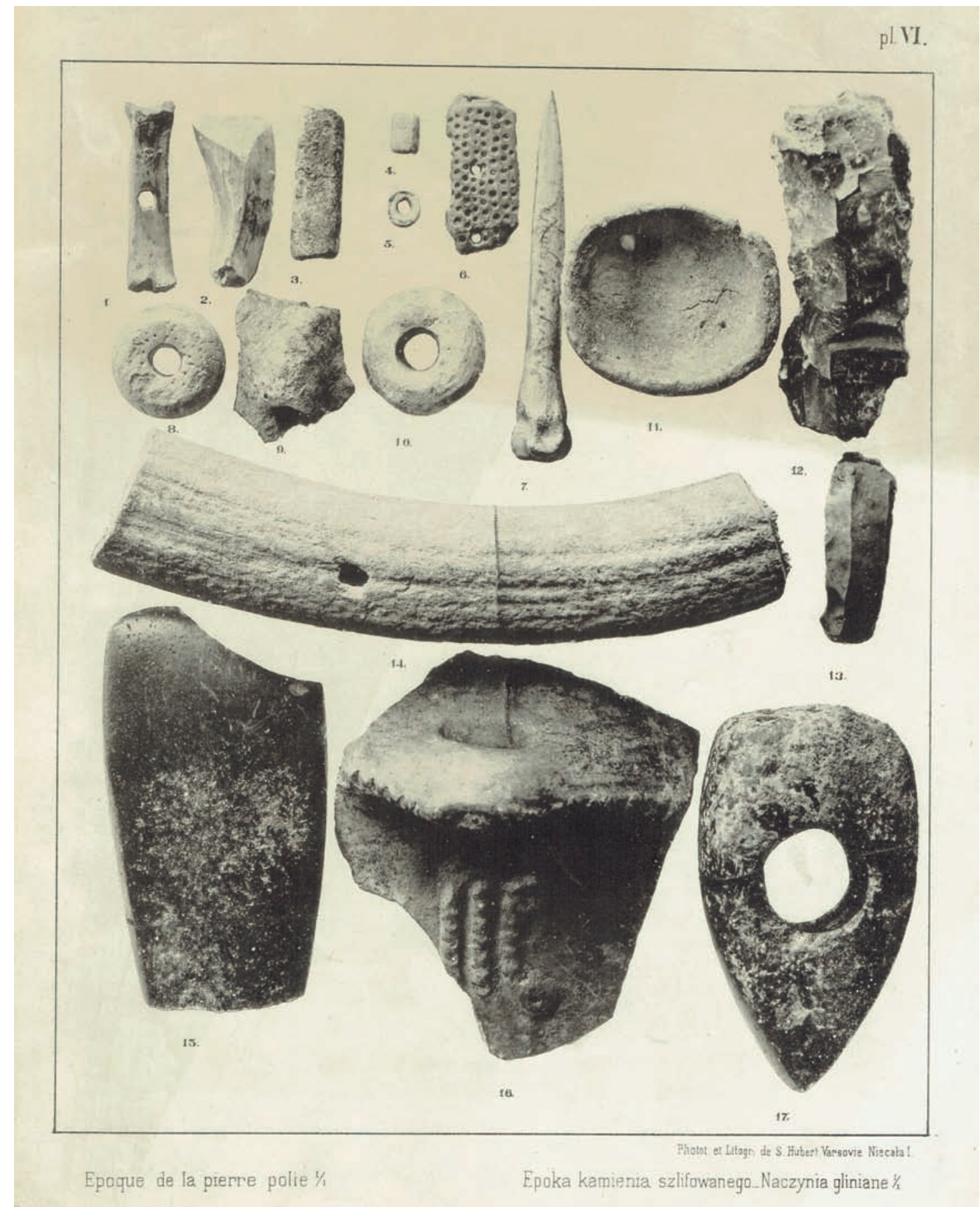

Ryc. 11. Tablica z zabytkami z badań J. Zawiszy w Jaskini Mamutowej. Muzeum Archeologiczne w Krakowie, Archiwum Fig. 11. A plate with artefacts uncovered by J. Zawisza in the Mammoth Cave. The Archaeological Museum in Krakow, Archives 
przede wszystkim o sprawach wojskowych i o polityce.

\section{WYPRAWA NA KRYM I KAUKAZ}

Robert Rudolf Schmidt i Leon Kozłowski na wyprawę w głąb Rosji wyruszyli wiosną 1914 roku. Naukowym celem tej podróży było odnalezienie śladów człowieka „dyluwialnego" (paleolitycznego) i zbadanie jaskiń nadczarnomorskich (list L. K. do W. Demetrykiewicza, 28 V 1914 r., MAK, sygn., SP8/36). Pierwsze poszukiwania nie dały oczekiwanych rezultatów - w maju Kozłowski pisał z Sewastopola, że nie udało im się dokonać żadnych odkryć. Ponieważ nad Dnieprem nie natrafili na jaskinie, ograniczyli się do zbadania

„stacji kijowskiej, która nie zawiera żadnych jak się okazało nadzwyczajności i jedynie błędne obserwacje itd. czyniły ją tak sensacyjną" (list L. K. do W. Demetrykiewicza, 18 V 1914 r., tamże).

Większe wykopaliska prowadzili dopiero w okolicach Bakczysaraju na Krymie, ale i tam nie przyniosły one ciekawych wyników. Po przeniesieniu się na leżący w paśmie Gór Krymskich Czatyrdah bez skutku eksplorowali kolejne jaskinie. Nie znalazłszy tam stanowisk paleolitycznych, postanowili udać się na południowy brzeg Krymu, a następnie na Kaukaz. W maju Leon Kozłowski podsumowywał przeprowadzone badania:

„(...) stwierdziliśmy, że człowiek dyluwialny nie zaszedł na Krym, obecne nasze badania będą miały na celu zbadać Kaukaz, gdy rezultat będzie negatywny, praojczyzny człowieka trzeba będzie szukać w Afryce północnej” (list L. K. do W. Demetrykiewicza, 28 V 1914 r., tamże).

Wykopaliska na Kaukazie (w jaskiniach Sakazja, Barataszwili i Uwarowa) Schmidt i Kozłowski rozpoczęli w czerwcu. Ze względu na coraz bardziej napiętą sytuację polityczną w przededniu Wielkiej Wojny, badania te prowadzili w pośpiechu i niezbyt metodycznie $^{11}$ (Kozłowski 2007, 62; por. Kot 2019,

11 Stronniczy i niechętny Kozłowskiemu i Schmidtowi opis ich pobytu na Kaukazie pozostawił badający jaskinie kaukaskie w 1916 roku Stefan Krukowski (Kozłowski 2007: 49-50 i 57-62).
54). Tym razem jednak udało im się natrafić na interesujące znaleziska ${ }^{12}$. Kozłowski relacjonował:

„Od dwóch tygodni mieszkam w namiocie i prowadzę rozkopy jaskini. Schmidt rozchorował się (...) tak, że musiał zostać w Kutaisie i dopiero jutro uda się w drogę do jaskini. Znaleziska są bardzo bogate: znaleźliśmy dwa, jedno nad drugim leżące paleniska, jedno Azylieńskie, drugie późno Aurignackie, oczekujemy jeszcze dalszych warstw. Jaskinia leży dwadzieścia minut drogi koleją od Kutaisu, w okolicy obfitującej w jaskinie, należy się spodziewać, że i w innych jaskiniach również znajdziemy bogate znaleziska" (list L. K. do W. Demetrykiewicza, 23 VI 1914 r., MAK, sygn. SP8/36).

Przebywając w Tyflisie (dzisiejszym Tbilisi), starał się także zapoznać z miejscowymi zbiorami. Szczególnie zainteresowały go materiały neolityczne (zwłaszcza ceramika malowana). Jednakże, ze względu na przenosiny tyfliskiego muzeum, większość zbiorów była $w$ tym czasie niedostępna, przez co udało mu się zobaczyć jedynie ich niewielką część (list L. K. do W. Demetrykiewicza, 23 VI 1914 r., tamże).

Wyprawa na Krym nie miała być ostatnią wspólną wyprawą obu badaczy. Schmidt planował zorganizowanie kolejnej podróży już w roku następnym, tym razem na tereny Azji Mniejszej, ale z powodu wojny planów tych nie udało się urzeczywistnić (tamże). Wyprawa na Krym i Kaukaz miała dla Leona Kozłowskiego ogromne znaczenie, także dlatego, że stanowiła swego rodzaju przepustkę do prowadzenia samodzielnych badań na stanowiskach paleolitycznych w Polsce. W lipcu 1914 roku Kozłowski pisał do Demetrykiewicza, że dzięki zdobytemu tam doświadczeniu nabył w zakresie techniki wykopaliskowej wystarczających umiejętności do prowadzenia badań w jaskiniach polskich (list L. K. do W. Demetrykiewicza, 5 VII 1914 r., tamże).

W czasie podróży na Wschód, na polecenie profesora Demetrykiewicza, Leon Kozłowski zajmował się zbieraniem informacji o materiałach przechowywanych w prywatnych kolekcjach, a także starał się o pozyskanie ciekawych zbiorów dla Muzeum Archeologicznego Akademii Umiejętności w Krakowie. Z Sewastopola pisał:

12 O wynikach prowadzonych wtedy badań Leon Kozłowski opowiadał później na jednym z posiedzeń Pracowni Antropologicznej Warszawskiego Towarzystwa Naukowego (Życiorys L. K., 1917 r., Teczka doktorska, Archiwum UJ, sygn. WF II 504). 
„Z poleceń, które wziąłem od Pana Profesora nie mogłem się dotychczas wywiązać pomimo usilnych starań, gdyż nigdzie dotychczas nie natrafiłem na zbiory w rękach prywatnych, a sam coś niezależnie zba[da]ć [?] też nie byłem w stanie; może dalsza podróż będzie bardziej owocną, szczególniej duże nadzieje pokładam na Kercz" (list L. K. do W. Demetrykiewicza, 18 V 1914 r., tamże).

I rzeczywiście, w mieście tym Kozłowskiemu udało się zdobyć dla Akademii niedużą kolekcję za- bytków. W większości były to artefakty z terenów Polski, ale także z okolic samego Kercza, a nawet, jak pisał, „zawartość jednej katakumby greckiej” (list L. K. do W. Demetrykiewicza, 28 V 1914 r., tamże). Zostały one częściowo sprzedane, a częściowo ofiarowane Akademii Umiejętności przez niejakiego pana Terleckiego, „który zbiera monety, rzeczy greckie, kupuje, sprzedaje zabytki" (tamże). Od Terleckiego Kozłowski dowiedział się także o znajdującym się w Kijowie zbiorze zabytków pradziejowych z tere-

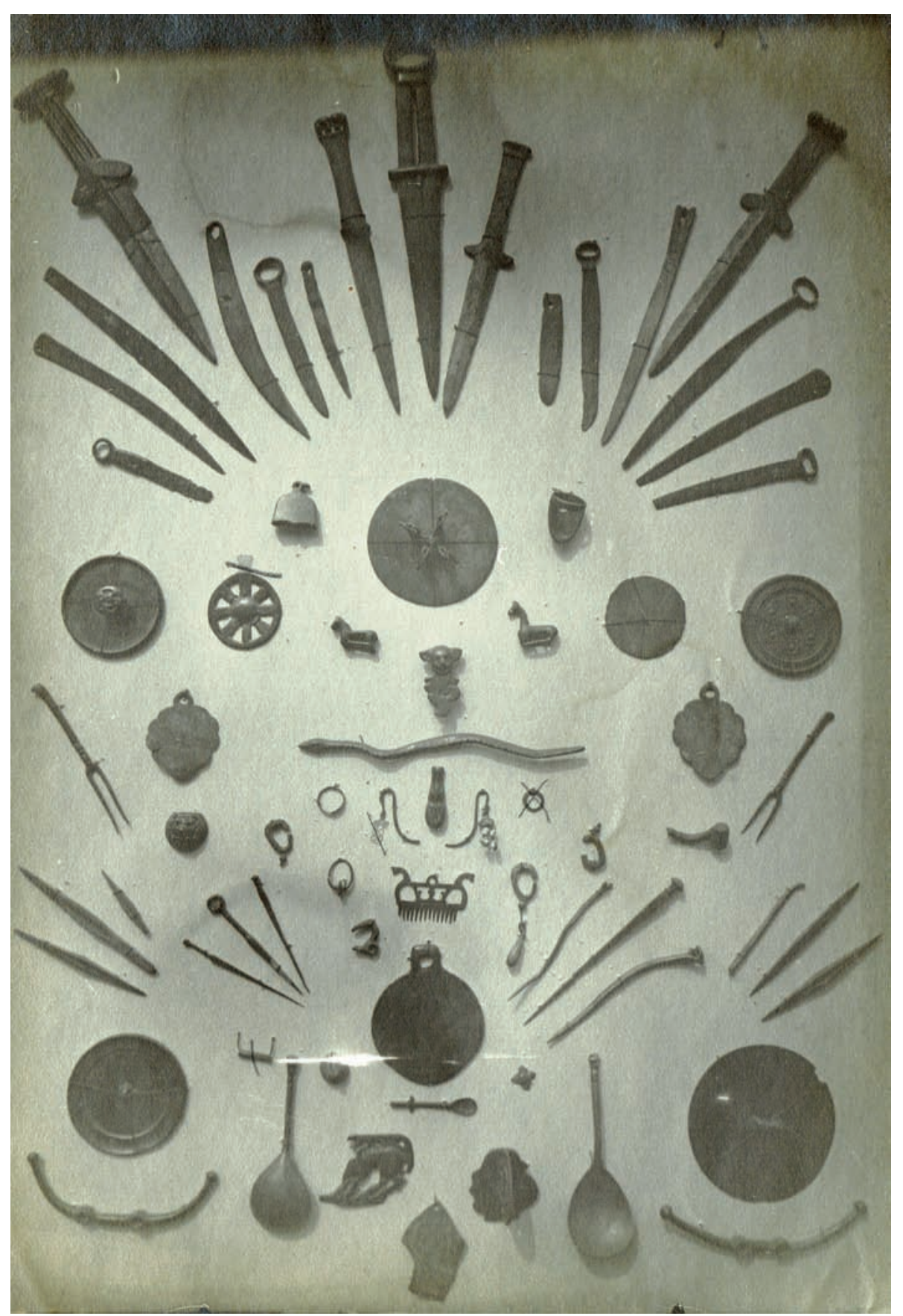

Ryc. 12. Fotografia części zbioru I. Strumiłło. 1914 r., Muzeum Archeologiczne w Krakowie, Archiwum, sygn. SP8/36 Fig. 12. A photo of artefacts from I. Strumiłło's collection, 1914. The Archaeological Museum in Kraków, 
nów Syberii. Pisał potem w tej sprawie do profesora Demetrykiewicza:

„Zbiór jest w polskich rękach w Kijowie do kupienia za 500 rub[li]. Mam przekonanie, że to jest dobry interes. Może udałoby się coś dla akademii wytargować. Fotografie większości okazów zabrałem. Jestem zdania, że należałoby zbiór ten kupić, może na spółkę z innym muzeum, ewentualnie za czterysta rubli. W każdym razie napiszę do wła- ścicieli z zapytaniem o szczegóły i o to, czy można część zbioru nabyć" (tamże).

O materiałach tych, należących do mieszkającej w Kijowie Idalii Strumiłło, Kozłowski pisał jeszcze z Kaukazu (ryc. 12, 13). Ponieważ żądana cena była wysoka, a Demetrykiewicz mógł chcieć pozyskać tylko część kolekcji, Kozłowski proponował wspólne nabycie zbioru przez Muzeum Akademii i Muzeum

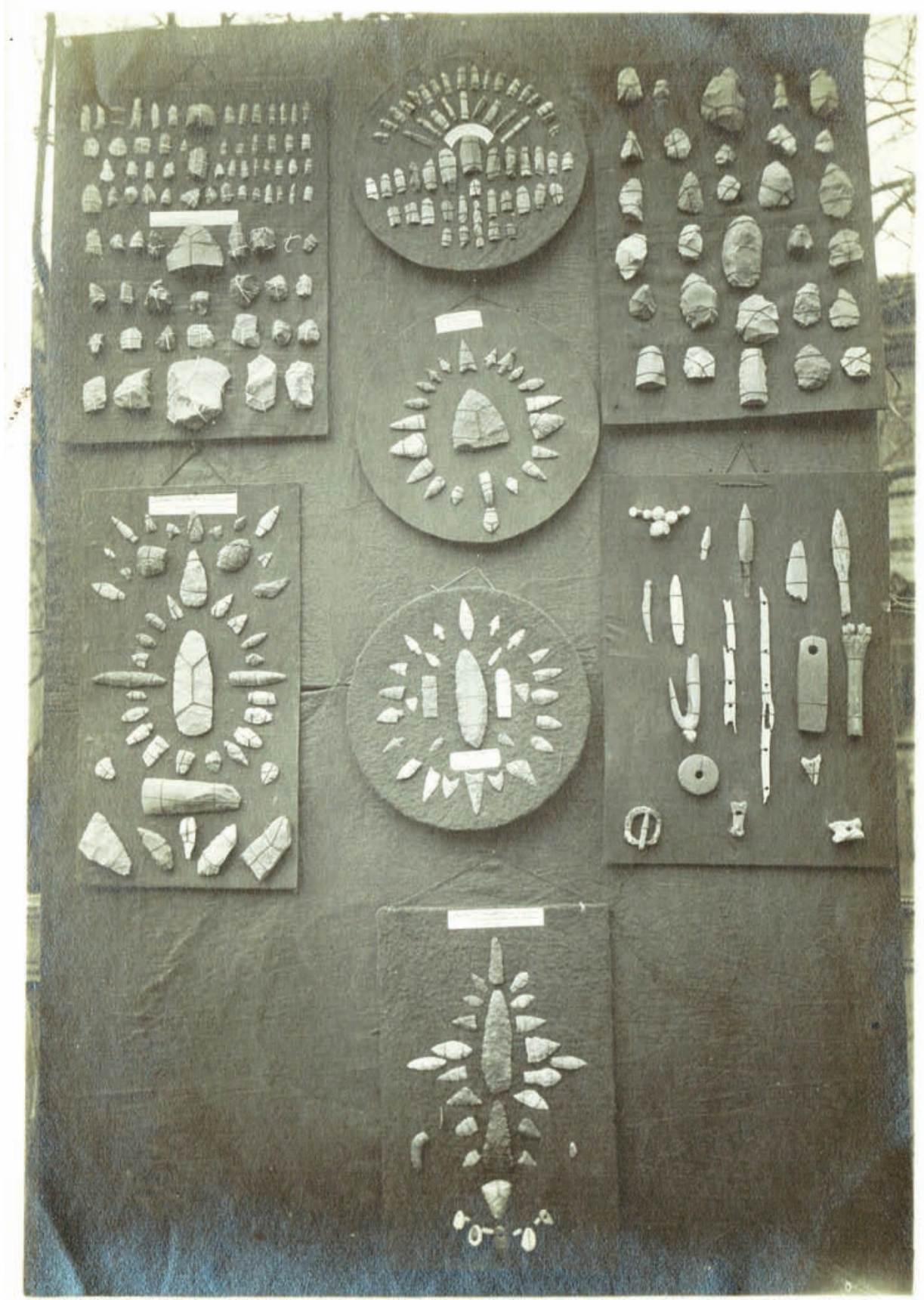

Ryc. 13. Fotografia części zbioru I. Strumiłło. 1914 r., Muzeum Archeologiczne w Krakowie, Archiwum, sygn. SP8/36

Fig. 13. A photo of artefacts from I. Strumiłło's collection, 1914. The Archaeological Museum in Kraków, Archives, sign. SP8/36 
Erazma Majewskiego. Dodawał, że sam zająłby się wszelkimi pertraktacjami w tej sprawie (list L. K. do W. Demetrykiewicza, 5 VII 1914 r., tamże). W przechowywanej w Muzeum Archeologicznym w Krakowie spuściźnie po Włodzimierzu Demetrykiewiczu zachował się list, jaki Leon Kozłowski napisał w tej sprawie do Idalii Strumiłło. Przedstawiał się w nim jako asystent Muzeum Akademii, a więc niejako reprezentant tej instytucji. Pytał o pochodzenie znalezisk, o możliwość zakupienia tylko części kolekcji, prosił także o informację, czy dla krakowskiego muzeum cena zbioru nie mogłaby być niższa. Zaznaczał, że środki tej instytucji były bardzo skromne, a ,nie chcielibyśmy zbioru tego z rąk polskich wypuścić” (list L. K. do I. Strumiłło, 1914 r., tamże). Kozłowski przekazał właścicielce adres profesora Demetrykiewicza, prosząc, by to $\mathrm{z}$ nim prowadziła dalsze rozmowy w tej sprawie. W trakcie prac wykopaliskowych prowadzonych w okolicach Kutaisu, Kozłowski porozumiał się także z mieszkającym w tym rejonie młodym Polakiem o nazwisku Jędrzejewski, który po ukończeniu szkoły średniej, w 1916 roku, zamierzał podjąć studia w Krakowie. Gimnazjalista ów obiecał, że będzie zbierał dla Akademii Umiejętności zabytki prehistoryczne wykonane z brązu i kamienia. Kozłowski spodziewał się, że dzięki jego pomocy Muzeum Akademii zyska kolekcję kaukaską, która, w jego opinii, nie była trudna do zebrania (list L. K. do W. Demetrykiewicza, 23 VI 1914 r., tamże).

Leon Kozłowski nie zapominał o Akademii Umiejętności także podczas badań prowadzonych z R. R. Schmidtem. Z początkiem lipca pisał z Kaukazu:

„Dla Muzeum Akademii prywatnie od Schmidt[a] dla siebie uzyskałem okazową kolekcję narzędzi paleolitycznych w liczbie 150-200 sztuk, oczywiście nie najgorszych okazów, będzie to wcale ładny zbiorek reprezentujący bardzo dobrze paleolit tutejszy i może być zaczątkiem okazowych kolekcji obcokrajowych w Muzeum Akademii” (list L. K. do W. Demetrykiewicza, 5 VII 1914 r., tamże).

Chcąc zapobiec możliwym kłopotom na granicy, Kozłowski zamierzał wysłać pozyskane dla Akademii zbiory do leżących w obrębie cesarstwa rosyjskiego rodzinnych Przybysławic. Po powrocie do Krakowa, który miał nastąpić w ciągu kilku tygodni, planował przewiezienie ich do Akademii (list L. K. do W. Demetrykiewicza, 28 V 1914 r., tamże). Zdeponowanych w Przybysławicach materiałów nie zdążył już jednak dostarczyć do Krakowa i w czasie wojny, podczas plądrowania przez Rosjan jego majątku, uległy one - wraz z innymi - zniszczeniu.

\section{W LATACH WIELKIEJ WOJNY}

Leon Kozłowski od początku swojego pobytu w Krakowie - oprócz działalności naukowej - aktywnie zajmował się polityką. Po przyjeździe do Galicji rzucił się w wir działalności niepodległościowej, angażując się w działalność Stowarzyszenia Młodzieży Postępowo-Niepodległościowej „Promień”, wstępując do zakonspirowanego Związku Walki Czynnej, a później także do Związku Strzeleckiego. W Krakowie poznał Józefa Piłsudskiego, z którym związany był aż do śmierci marszałka w 1935 roku (Perkowska 1990, 12-15, M. Kozłowski 2005, 24-25; Lech, Piotrowska 2006, 172-173). Na przełomie lipca i sierpnia 1914 roku, kiedy Piłsudski zarządził mobilizację podlegających mu oddziałów, Leon Kozłowski rozpoczął swoją wojenną ,przygodę”, w której dosłużył się stopnia wachmistrza (później podporucznika) i Krzyża Walecznych (ryc. 14). Najpierw zajął się realizacją zadań politycznych - został wysłany na tereny Królestwa Polskiego, gdzie miał nawoływać do antyrosyjskiego powstania. Dopiero 1 listopada 1914 roku wstąpił do I Pułku Ułanów Beliny-Prażmowskiego (M. Kozłowski 2005, 27-29).

W czasie wojny, kiedy pozwalały na to okoliczności, Kozłowski kontaktował się z przebywającym najpierw w Wiedniu, a później w Szwajcarii profesorem Demetrykiewiczem. Pod koniec 1915 roku informował go o swoich losach. Pisał:

„(...) przez pierwsze trzy miesiące byłem w tak zwanej służbie cywilnej polskiej organizacji narodowej i byłem naprzemian: zastępcą naczelnika powiatu, naczelnikiem powiatu, werbownikiem, agitatorem, mówcą (...) zależnie od warunków, okoliczności i sytuacji wojennej i politycznej. 1 listopada wstąpiłem do Kawalerii, odbyłem przemarsz z Miechowa do Krakowa przez środek wojsk rosyjskich, Kampanię podhalańską, bitwę pod Limanową, walki na[d] Dunajcem, bitwę pod Łowczówkiem, walki pozycyjne nad Nidą, wreszcie ofensywę znad Nidy, w której brałem udział aż pod Lublin przeszedłszy ogółem przez 20 bitew, pod Lublinem byłem już całkowicie wyczerpany i przydzielono mnie do służby organizacyjnej w końcu lipca 1915 r. W pierwszych dniach września złamałem nogę i na miesiąc położyłem się do łóżka, a następnie jeszcze cały październik byłem na rekonwalescencji. W pierwszych dniach listopada zwolniony zostałem od służby liniowej 


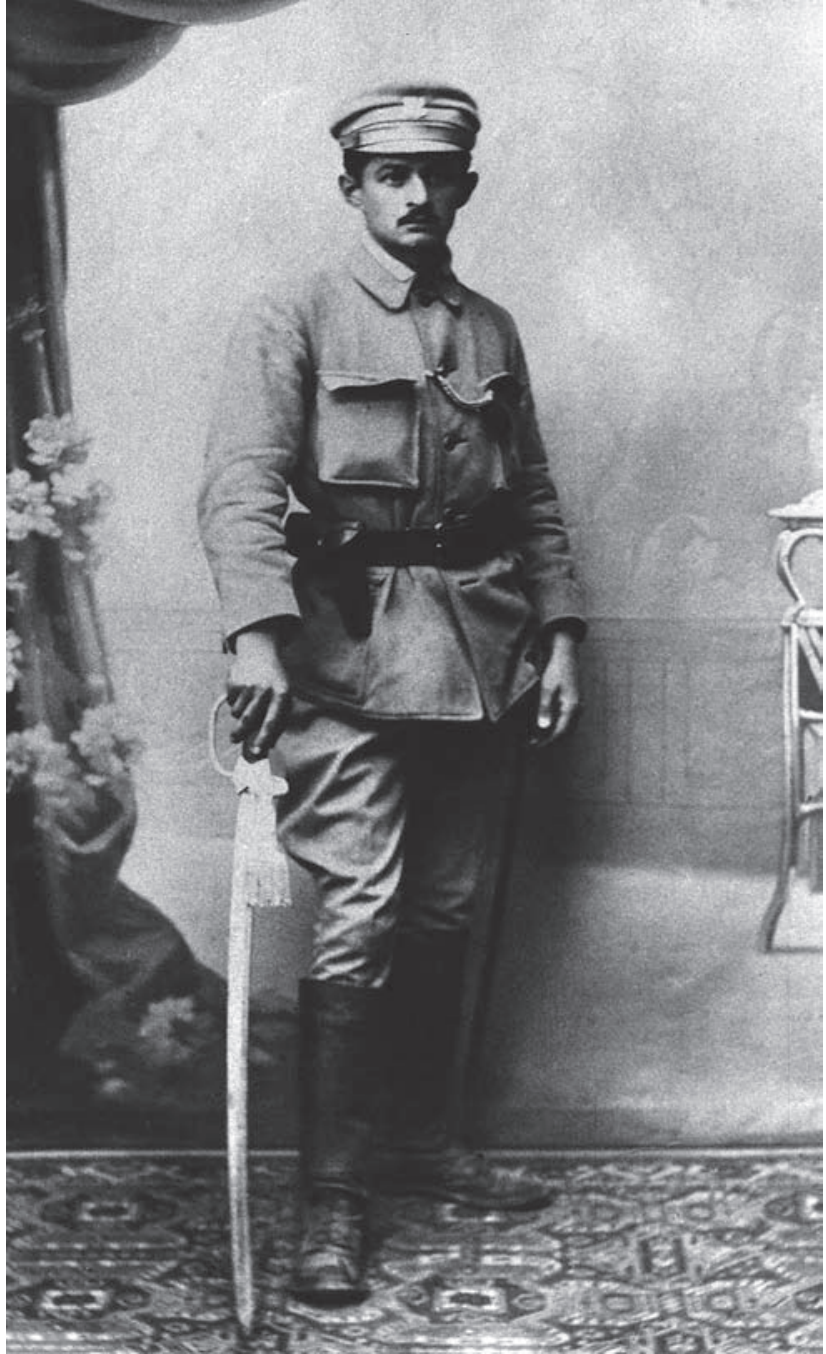

Ryc. 14. Leon Kozłowski podczas Wielkiej Wojny. Fot. za: Lech, Piotrowska 2006

Fig. 14. Leon Kozłowski during the Great War. Photo provided in Lech, Piotrowska 2006

i odesłany dla robót organizacyjnych do Kielc (...)" (list L. K. do W. Demetrykiewicza, 20 XI 1915 r., MAK, sygn. SP8/36).

Później jeszcze przyszło aresztowanie w Zamościu przez austriackie władze skonfliktowane z wierną Piłsudskiemu I Brygadą i ponad siedem miesięcy spędzonych w więzieniu, po oskarżeniu o werbowanie żołnierzy do jego oddziałów (M. Kozłowski 2005, 29-30).

Tymczasem w Krakowie, wkrótce po wybuchu wojny, Akademia Umiejętności stanęła przed ważnym problemem zabezpieczenia stanowisk archeologicznych odkrywanych przy budowaniu wojennych umocnień i fortyfikacji. Na jednym z nich, w Skotnikach pod Krakowem (obecnie Kraków-Skotniki), natrafiono na cmentarzysko prehistoryczne. Wobec nieobecności Demetrykiewicza sprawą zajął się Stanisław Tomkowicz (1850-1933), konserwator zabytków i przewodniczący Komisji Historii Sztuki Akademii Umiejętności. Podjął on starania o pozyskanie do zbiorów Akademii znalezisk i o uzyskanie zgody władz wojskowych na prowadzenie badań. Przebywający za granicą Demetrykiewicz, także dzięki korespondencji z Tomkowiczem, był dobrze zorientowany w tych problemach. Nie mogąc osobiście zaangażować się w sprawę, w przesyłanych do Krakowa listach starał się udzielać potrzebnych rad i wskazówek. Polecał także swoich uczniów - Michała Drewkę i Leona Kozłowskiego, którzy w jego ocenie zdobyli już wystarczające doświadczenie, by można im było powierzyć sprawy konserwatorskie. O Kozłowskim Demetrykiewicz pisał:

„Drugi mój uczeń, którego do celów (...) opieki nad wykopaliskami mogę gorąco polecić, jest p[an] Leon Kozłowski, syn obywatela ziemskiego z Przybysławic w powiecie Miechowskim w Królestwie. P[an] Kozłowski z początku wojny służył w legionach, lecz rzekomo z początkiem b[ieżącego] roku musiał wystąpić z szeregów z powodu nadwyrężonego zdrowia. Obecnie p[an] Kozłowski ma bawić w swej wsi rodzinnej w Przybysławicach. Należałoby to sprawdzić chcąc go do zadań archeologicznych spożytkować. Projektowałbym użyć p[ana] Kozłowskiego przede wszystkim na terenach Królestwa polskiego. Okolice te dobrze zna i ma wiele nawiązanych stosunków znajomości i pokrewieństwa między obywatelstwem Królestwa. P[an] Kozłowski studiował prehistorię w Krakowie i w Tybindze u głośnego prof. R. Schmidta, z którym podjął nawet podróż naukową archeologiczną do południowej Rosji i na Kaukaz. Technikę wykopaliskową zna doskonale i pracował już samodzielnie na terenach Królestwa (dla Muzeum p[ana] Erazma Majewskiego w Warszawie)" (list W. Demetrykiewicza do S. Tomkowicza i T. Szydłowskiego, 26 VIII 1915 r., brulion, MAK, sygn. SP8/20).

Leon Kozłowski przebywał jednak poza Krakowem, więc w maju 1916 roku Komisja Antropologiczna AU poleciła przeprowadzenie badań ratowniczych w Skotnikach Michałowi Drewce, studiującemu w tym czasie w Krakowie Włodzimierzowi Antoniewiczowi (1893-1973), późniejszemu profesorowi archeologii prehistorycznej na Uniwersytecie Warszawskim, a także badaczowi o nazwisku Wisłocki. Ostatecznie badania w Skotnikach przeprowadził w 1917 roku Antoniewicz (Sprawozdania z posiedzeń 1919, XII-XV, XXIII-XXIV; Antoniewicz 1920). 
Na początku wojny przepadły zbiory Akademii, które Leon Kozłowski przechowywał w swoim domu w Przybysławicach, w powiecie miechowskim (ryc. 15). W jednym $z$ listów Kozłowski informował później, że w listopadzie 1914 roku, w trakcie ofensywy na Kraków, Rosjanie splądrowali jego majątek, niszcząc wraz z wyposażeniem domu wszystkie przechowywane w nim zabytki. Pisał:

„Zbiory były spakowane w skrzynie i złożone w jednym pokoju; pierwszą rzeczą moskali było rozbić skrzynie, a gdy znaleźli zabytki wszystko ze skrzynek i pakietów wyrzucili, a następnie wywieźli na drogę. $Z$ rzeczy, które były własnością akademii zginęły groby kujawskie i skrzynia kupionych rzeczy na Krymie" (list L. K. do W. Demetrykiewicza, 20 XI 1915 r., MAK, sygn. SP8/36).

Demetrykiewicz rozsierdził się na Kozłowskiego z powodu zniszczenia tych materiałów. W grudniu 1915 roku pisał do opiekującego się pod jego nieobecność Muzeum Michała Drewki z prośbą o zabezpieczenie znajdujących się w Akademii książek. Życzył sobie, by korzystano z nich wyłącznie na miejscu. Pisał:

„Boję się np.p[ana] Kozłowskiego, gdyby przyjechał, bo on nie umie pilnować i szanować książek. Dowód, że nie zabezpieczył swoich rzeczy i naszych zabytków złożonych w jego dworze. Niebezpieczeństwo napadu można było przewidzieć i wcześnie wszystko przewieźć, choćby do Czarnowskiego. Przez lekkomyślność i brak przezorności zmarnował wszystko" (list W. Demetrykiewicza do M. Drewki, brulion, 28 XII 1915 r., tamże).

Pod koniec 1915 roku, Leon Kozłowski wciąż jeszcze wiązał swoją przyszłość z Akademią Umiejętności w Krakowie i z Uniwersytetem Jagiellońskim. W liście napisanym w tym czasie do Włodzimierza Demetrykiewicza wspominał, że choć działania wojenne nie pozwalały mu na powrót do nauki, to wciąż chciałby kontynuować swoją pracę w Krakowie. Podkreślał, że nie interesowały go możliwości, jakie otwierały się przed archeologią w Warszawie, na organizowanym tam uniwersytecie (list L. K. do W. Demetrykiewicza, 20 XI 1915 r., tamże). Pytając profesora Demetrykiewicza o losy kolegów z Krakowa, pisał o „naszym muzeum” (tamże). Jednak zawikłana sytuacja polityczna i groźba aresztowania za udział w tworzeniu struktur Polskiej Organizacji Wojskowej w okręgu radomskim zmusiła Kozłowskiego do opuszczenia terenów zajmowanych przez wojska austriackie. Postanowił wyjechać do okupowanej przez Niemców Warszawy, gdzie, chcąc przeczekać niebezpieczny okres, powrócił do pracy naukowej

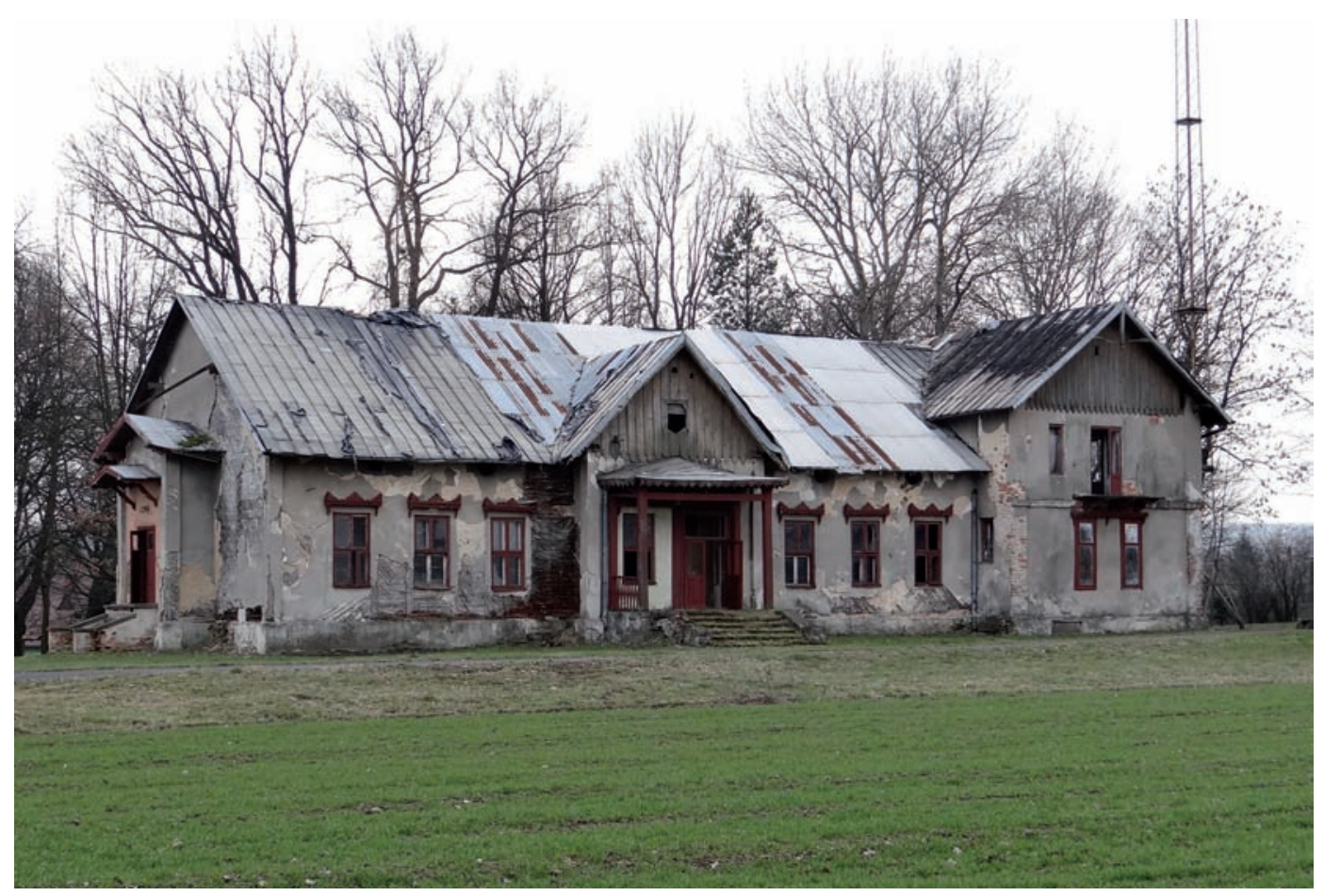

Ryc. 15. Dwór w Przybysławicach, pow. Miechów. 2016 r. Fot. Domena publiczna

Fig. 15. The manor house in Przybysławice, Miechów district, 2016. Photo from public domain 
(L. Kozłowski 2005, 218; M. Kozłowski 2005, 2930). Pisał później do Demetrykiewicza:

„Trafiłem na okres organizowania się muzeum miejskiego, do którego p[an] E[razm] Majewski ofiarować postanowił swoje zbiory. Muzeum otrzymało gmach na Podwalu, w którym na archeologię przypadło 6 sal. Pracę przeprowadzenia zbiorów podjąłem. Na okres przeprowadzki przyjechał $\mathrm{p}$ [an] Kostrzewski i z nim razem nad uporządkowaniem muzeum pracowałem, biorąc na siebie epokę kamienną. Po wyjeździe p[ana] Kostrzewskiego sam robotę dalej prowadziłem, aż do 1 lutego bieżącego roku. Muzeum zostało całkowicie uporządkowane i usystematyzowane, napisaliśmy również z Kostrzewskim przewodnik po muzeum, który jest pod prasą" (list L. K. do W. Demetrykiewicza, 22 III 1917 r., MAK, sygn. SP8/36).

To właśnie w Warszawie, w oparciu o zbiory Erazma Majewskiego, Leon Kozłowski napisał pracę Epoka kamienia na wydmach wschodniej części Wyżyny Małopolskiej, która stała się jego rozprawą doktorską (Kozłowski 1923; 1925b; por. Sawicki 1925; Kozłowski 1993, 56). Pisał później do profesora Demetrykiewicza:

„Mając dostęp niekrępowany niczym do zbiorów, przystąpiłem do opracowania mikrolitu, który na nowo ułożyć wypadło. Cały materiał z gruntu przerobiłem i napisałem większe studium pod tytułem »Mezolit i neolit na wschodnim obszarze wyżyny Małopolskiej «" (list L. K. do W. Demetrykiewicza, 22 III 1917 r., MAK, sygn. SP8/36).

Kiedy jednak ucichły już echa jego działalności w Radomskiem, Kozłowski postanowił powrócić na tereny kontrolowane przez Austriaków i ponownie zająć się działalnością niepodległościową. Udał się do Kielc, gdzie organizował struktury Polskiej Organizacji Wojskowej i kontynuował pracę naukową, zajmując się materiałami z wydm kieleckich i ceramiką kultury złockiej (tamże; M. Kozłowski 2005, 30). W 1917 roku prowadził także krótkie poszukiwania archeologiczne w paśmie Krakowsko-Wieluńskim, sondując tamtejsze jaskinie (Lech, Piotrowska 2006, 175).

\section{DOKTORAT. LATA 1917-1918}

Po ukończeniu pracy o epoce kamienia we wschodniej części Wyżyny Małopolskiej, Leon Kozłowski rozpoczął starania o uzyskanie stopnia dok- tora antropologii na Uniwersytecie Jagiellońskim. Ze względu na wymogi formalne, w marcu 1917 roku zwrócił się do Ministerstwa Wyznań i Oświecenia w Wiedniu, z prośbą o zaliczenie mu do wymaganych lat studiów pięciu semestrów, w czasie których pobierał nauki w trybie nadzwyczajnym (Teczka doktorska L. K., Archiwum UJ, sygn. WF II 504). Rada Wydziału Filozoficznego UJ poparła wniosek skierowany do Wiednia (Protokoły posiedzeń Rady Wydziału Filozoficznego, Posiedzenie z dnia 23 III 1917 r., Archiwum UJ, sygn. WF II 47, k. 211) i Kozłowski, po przedstawieniu swojej rozprawy, został dopuszczony do tzw. rygorozów, czyli egzaminów ścisłych przed uzyskaniem stopnia doktorskiego (Corpus studiosorum 2009, 538). W marcu 1917 roku poruszał sprawę doktoratu w liście do Włodzimierza Demetrykiewicza. Pisał:

„Planem moim jest, aby możliwie szybko po powrocie Szanownego Pana Profesora móc siąść do egzaminów. Chodziło mi więc o to, aby wszelkie poboczne przedmioty można było sobie już uprzednio przygotować. Zdawać mogę tylko w grupie Antropologia z prehistorią jako przedmiot główny, geologia jako poboczny. Referentami pracy w obecnej chwili byliby prof. Hoyer i Wrzosek do Antropologii, prof. Szajnocha do geologii. Z chwilą powrotu Pana Profesora osoba Jego, co samo przez się się rozumie, weszłaby w skład Komisji i Pan Profesor byłby głównym referentem pracy. $Z$ prof. Hoyerem i prof. Szajnochą rozmawiałem co do materiału, jaki mam przygotować. $Z$ podaniem jednak pracy i zgłoszeniem się do egzaminów czekać będę na powrót Wielce Szanownego Pana Profesora i na omówienie z Nim wszystkich spraw złączonych z tym aktem. Obecnie zaś zajmę się wykończeniem pracy doktorskiej i przygotowaniem się do egzaminu z Antropologii i Geologii" (list L. K. do W. Demetrykiewicza, 22 III 1917 r., MAK, sygn. SP8/36).

Rozwiązanie zaproponowane przez Kozłowskiego wydawało się być wtedy możliwe do zrealizowania - nikt nie przypuszczał, że pobyt Demetrykiewicza poza granicami kraju będzie trwał aż do 1919 roku.

Tymczasem w naukowe plany Leona Kozłowskiego raz jeszcze wkroczyła polityka. Po aresztowaniu przez władze państw centralnych Józefa Piłsudskiego i działaczy Polskiej Organizacji Wojskowej, Kozłowski, przeczuwając niebezpieczeństwo, zdecydował się opuścić kraj. W Tybindze, dokąd się udał, postanowił sfinalizować sprawę swojego doktoratu (L. Kozłowski 2005, 218; M. Kozłowski 2005, 30). $\mathrm{W}$ mieście tym, gdzie przebywał $\mathrm{w}$ roku akademic- 
kim 1917/1918, studiował prehistorię, geologię, geografię i archeologię klasyczną. Złożył tam również swoją rozprawę i 11 sierpnia 1918 roku został promowany na stopień doktorski z geologii, jako przedmiotu głównego oraz geografii i archeologii klasycznej jako przedmiotów pobocznych (Teczka habilitacyjna L. K., Archiwum UJ, sygn. WF II 121; Godlewski 2010, 320324). Pewne informacje na temat okoliczności obrony jego doktoratu zachowały się $\mathrm{w}$ jednym $\mathrm{z}$ listów Michała Drewki do Włodzimierza Demetrykiewicza. W czerwcu 1918 roku informował on:

„Kozłowski dotychczas do Krakowa nie przyjechał, ale należy się go spodziewać, skoro tylko upora się z doktoratem. Nie pozwolono mu zdawać z archeologii u Schmidta, więc o ile słyszałem, ma zdawać doktorat $\mathrm{z}$ geografii w Tybindze. Potem chciałby zabrać się w Krakowie do opracowania »Mamutowej«. Do stałego pobytu w Warszawie, mimo braku ludzi tamże, nie ma jakoś wielkiej ochoty"13 (list M. Drewki do W. Demetrykiewicza, 28 VI 1918 r., MAK, sygn. SP8/36).

Po powrocie z Tybingi, jesienią 1918 roku, Leon Kozłowski zajął się badaniami w Jaskini Nietoperzowej w Jerzmanowicach. W tym czasie doszło do słynnego konfliktu pomiędzy nim a badającym Jaskinię Ciemną Stefanem Krukowskim (Kozłowski 1922, 2932; Lech 2001, 137; Lech, Piotrowska 2006, 175-180; Piotrowska 2006, 194-196; Kozłowski 2007, 63-65). Jesienią 1918 roku Kozłowski zdawał się już jednak poważnie wiązać swoje plany na przyszłość z Warszawą. Do Krakowa zaglądał rzadko.

Drewko pisał:

,[Kozłowski] Osiadł już w Warszawie i jest urzędnikiem Muzeum Majewskiego" (list M. Drewki do W. Demetrykiewicza, 12 X 1918 r., MAK, sygn. SP8/36).

13 Podobną opinię o powrocie Leona Kozłowskiego do Krakowa wyrażał także Włodzimierz Antoniewicz. W jednym z listów pisał: „W przyszłym miesiącu ma wrócić kol[ega] Kozłowski i ma zamieszkać w Krakowie, przybędzie więc jeszcze jeden członek do narad takowych [o sprawach prehistorii, prowadzonych w Muzeum Akademii przez W. Antoniewicza i M. Drewke - przyp. aut.] (...)" (list W. Antoniewicza do W. Demetrykiewicza, 23 V 1918 r., MAK, sygn. SP8/36).

\section{POWRÓT DO WARSZAWY. PLANY OBJECIA KATEDRY PO ERAZMIE MAJEWSKIM}

Po przybyciu do Warszawy Leon Kozłowski wciąż podtrzymywał kontakty z Krakowem. W przesyłanych do profesora Demetrykiewicza listach informował o swoich planach naukowych i sprawach, którymi żyło warszawskie środowisko prehistoryków. W tym czasie Kozłowski dążył do objęcia stanowiska zastępcy poważnie już chorego Erazma Majewskiego na utworzonej w 1919 roku na Uniwersytecie Warszawskim katedrze archeologii prehistorycznej. Angażował się także w działania związane $\mathrm{z}$ organizowaniem Państwowego Grona Konserwatorów Zabytków Przedhistorycznych. W Warszawie miał jednak konkurenta - młodego i również bardzo zdolnego archeologa - Włodzimierza Antoniewicza, polecanego Erazmowi Majewskiemu przez Józefa Kostrzewskiego. Już wkrótce miało się okazać, że Erazm Majewski to właśnie jego wybierze do pomocy na Uniwersytecie, obawiając się ambicji swojego dawnego ucznia (Stolpiak 1984, 48-50; Kozłowski 1993, 53-57; Lech, Piotrowska 2006, 164). Antoniewicz objął także ważną funkcję w Państwowym Gronie Konserwatorów Zabytków Przedhistorycznych, gdzie również jako zastępca Majewskiego (będącego przewodniczącym Grona), właściwe kierował tą instytucją (Tymczasowy sktad 1920).

Leon Kozłowski, informując Demetrykiewicza o sytuacji w Warszawie, wspominał o sprawach związanych z Muzeum Majewskiego i pogarszającym się stanie zdrowia jego twórcy. Licząc na objęcie stanowiska zastępcy Majewskiego na Uniwersytecie pisał:

„Bardzo ze wszystkich stron przynaglają mnie, bym szybko sprawy swoje [czyli habilitacje - przyp. aut.] w Krakowie posuwał naprzód, tym samym bowiem wszelkie trudności będą usunięte, gdy ja swoje veniam docendi tu złożęe" (list L. K. do W. Demetrykiewicza, 16 II 1920 r., MAK, sygn. SP8/36).

\section{HABILITACJA NA UNIWERSYTECIE JAGIELLOŃSKIM}

Starania o habilitację w Krakowie Leon Kozłowski rozpoczął w 1920 roku, przedstawiając jako wymaganą rozprawę nieopublikowaną jeszcze pracę Groby megalityczne na wschód od Odry (Kozłowski 1921). Stroną formalną habilitacji dwudziestosiedmioletnie- 
go wówczas badacza zajmował się przede wszystkim obecny już od roku w Krakowie Włodzimierz Demetrykiewicz. To on, na posiedzeniu Rady Wydziału Filozoficznego, przedstawił rozprawę Kozłowskiego i wnioskował o dopuszczenie go do dalszego postępowania habilitacyjnego, na co Rada zgodziła się jednogłośnie (Protokoły posiedzeń Rady Wydziału Filozoficznego, Posiedzenie z dnia 16 IV 1920 r., Archiwum UJ, sygn. WF II 48, k. 106'). Pracę Groby megalityczne na wschód od Odry - skrytykowaną później przez Józefa Kostrzewskiego - (Kostrzewski 1922; 1970, 122-123), oceniało trzech profesorów - geolog i paleontolog Władysław Szajnocha (1857-1928), antropolog Julian Talko-Hryncewicz (1850-1936) oraz prehistoryk Włodzimierz Demetrykiewicz. Została przez nich uznana za „zupełnie zadowalniającą” (Teczka habilitacyjna L. K., Archiwum UJ, sygn. WF II 121). Wystawiając Leonowi Kozłowskiemu potrzebną opinię, profesor Demetrykiewicz pisał:

„Studia Dra Kozłowskiego szły przeważnie w kierunku przyrodniczym, przy czym znaczną rolę odgrywała geologia i paleontologia, dlatego też poświęciwszy się prehistorii zwrócił się Dr Kozłowski głównie do epok kamiennych t.j. do paleolitu i neolitu, w których najwięcej pracował. Z tego tytułu może Dr Kozłowski uchodzić poniekąd za specjalistę do epoki kamiennej ziem polskich i habilitacja jego jest pożądaną w interesie naszej prehistorii" (Opinia Włodzimierza Demetrykiewicza w sprawie habilitacji Leona Kozłowskiego, [1920 r.], MAK, sygn. SP 20/6).

Kolokwium habilitacyjne Leona Kozłowskiego odbyło się 24 kwietnia 1920 roku w sali posiedzeń Wydziału Filozoficznego. Wykład habilitacyjny, traktujący o kulturach neolitycznych w Polsce, został przez niego wygłoszony dwa dni później ${ }^{14}$. Pod koniec maja 1920 roku władze Wydziału Filozoficznego zwróciły się do Ministerstwa Wyznań Religijnych i Oświecenia Publicznego w Warszawie z prośbą o zatwierdzenie uchwały Grona Profesorów o udzieleniu Leonowi Kozłowskiemu veniam docendi z zakresu prehistorii (Teczka habilitacyjna L. K., Archiwum UJ, sygn. WF II 121). Minister W. R. i O. P. zatwierdził tę uchwałę, domagając się jednakże złożenia wniosku o nostryfikację dyplomu doktorskiego Leona Kozłow-

14 Temat tego wykładu został wybrany spośród trzech zaproponowanych przez L. Kozłowskiego. Tytuły pozostałych brzmiały: „Relatywny wiek polskiego paleolitu” i „Główne problemy polskiej prehistorii” (Teczka habilitacyjna L. K., Archiwum UJ, sygn. WF II 121). skiego, nadanego mu przez Uniwersytet w Tybindze. Za sprawą starań administracji Uniwersytetu Jagiellońskiego dyplom nostryfikowano i Kozłowski został docentem prywatnym prehistorii na krakowskiej uczelni (tamże). Na stanowisku tym był oficjalnie zatrudniony w roku akademickim 1920/1921 (Perkowska 2007, 182). Jednak mimo iż instytucja docentów prywatnych odgrywała ważną rolę w rozwoju Wydziału Filozoficznego UJ, warunki, jakie oferował Uniwersytet pracującym w tym charakterze pracownikom naukowym, nie były satysfakcjonujące (Michalewska 1997, 232). W Memoriale docentów prywatnych Uniwersytetu Jagiellońskiego w Krakowie pisano, iż docent prywatny, uzyskawszy veniam legendi, zaciągał wobec Uniwersytetu formalne zobowiązanie prowadzenia wykładów, którego zaniedbanie pociągało za sobą skutek karny. Gdyby bowiem docent przez trzy kolejne półrocza nie wykładał bez usprawiedliwionego powodu, wydział miał prawo odebrać mu veniam legendi. Tymczasem, w zamian za wykłady, nie otrzymywał on ani od Uniwersytetu, ani od państwa żadnego wynagrodzenia, pobierając jedynie opłacane przez uczniów czesne ( $W$ sprawie docentury prywatnej [1919-1920], 3).

$\mathrm{W}$ niedługim czasie po uzyskaniu habilitacji Leon Kozłowski przedstawił program swoich przyszłych zajęć. W ciągu trzech semestrów miał wygłaszać wykłady kursowe zatytułowane: „Metodyka prahistorii”, „O najstarszych zabytkach ludzkich” i „Młodsza epoka kamienna w Europie” (Teczka habilitacyjna L. K., Archiwum UJ, sygn. WF II 121). Prawdopodobnie już wtedy zdecydowany był jednak nie wiązać się z Uniwersytetem Jagiellońskim (Stolpiak 1984, 49); projektowanych wykładów nigdy nie wygłosił. Kiedy zintensyfikowały się działania wojenne na froncie trwającej właśnie wojny polsko-bolszewickiej, zostawił Uniwersytet i wstąpił do wojska, gdzie dosłużył się stopnia podporucznika (M. Kozłowski 2005, 31; Lech 2006, 38). Do Krakowa miał już nie powrócić.

\section{OBJECCIE KATEDRY ARCHEOLOGII PRZEDHISTORYCZNEJ WE LWOWIE}

Po zakończeniu wojny, w 1921 roku, Leon Kozłowski, na mocy postanowienia Naczelnika Państwa został mianowany nadzwyczajnym profesorem archeologii przedhistorycznej ze szczególnym uwzględnieniem ziem polskich, na Uniwersytecie Jana Kazimierza we Lwowie (M. Kozłowski 2005, 
32; Lech 2006, 38; Sytnyk 2006, 130-132; 2010, 129 131; Bilas 2010, 329; 2018, 436). W listopadzie tego roku pisał krótko do Demetrykiewicza o swoich nowych obowiązkach:

„Zwolna zaczynam się oswajać i przystosowywać do Lwowa. Wykłady rozpocząłem i zaczynam organizować instytut. Zostałem także współpracownikiem muzeum Dzieduszyckich, gdzie przystępuję do tworzenia inwentarza kartkowego oraz naukowego zestawienia zbiorów" (list L. K. do W. Demetrykiewicza, 8 XI 1921 r., MAK, sygn. SP8/36).

Objęcie katedry przez Leona Kozłowskiego wzbudziło wątpliwości zarówno Włodzimierza Demetrykiewicza, jak i Józefa Kostrzewskiego, zajmującego wówczas poznańską katedrę prehistorii i nazwanego później przez Konrada Jażdżewskiego głównym adwersarzem Kozłowskiego (Jażdżewski, Jędruszczak 1970, 20). W liście skierowanym do Demetrykiewicza Kostrzewski wyrażał zaniepokojenie faktem, iż nominacja Kozłowskiego nastąiła bez tzw. plebiscytu, czyli zasięgnięcia opinii innych profesorów danej specjalności. Kostrzewski wątpił, by w plebiscycie mógł on uzyskać przychylne dla siebie głosy. Zarzucał Kozłowskiemu niedbałość i lekkomyślne formułowanie teorii naukowych ${ }^{15}$. Kostrzewski zwracał się do Demetrykiewicza z pytaniem, czy nie należałoby zakwestionować ważności profesury Kozłowskiego i zastanawiał się, czy zbiorowy protest trzech profesorów prehistorii - Demetrykiewicza, Majewskiego i jego nie mógłby wpłynąć jej unieważnienie. Zaznaczał jednocześnie, że nie żywił wobec Kozłowskiego osobistych uprzedzeń i że z „czysto ludzkiego stanowiska” byłoby mu przykro wszczy-

15 Jednak pomimo tej krytyki, wypowiadanej zresztą wielokrotnie, Józef Kostrzewski nie odmawiał Leonowi Kozłowskiemu naukowych zasług. W opublikowanym w Przeglądzie Archeologicznym pośmiertnym wspomnieniu o tym uczonym Kostrzewski napisał między innymi: „Z Kozłowskim zeszła do grobu jedna z najwybitniejszych postaci wśród prehistoryków polskich. Obdarzony lotną wyobraźnią, kierował się on w swych badaniach naukowych raczej intuicją niż szczegółową analizą faktów i stąd wynikały nieraz pewne niezgodności między głoszonymi przezeń tezami a przytaczanym na ich poparcie materiałem wykopaliskowym. Trzeba jednak przyznać, że w niektórych wypadkach pomysły Kozłowskiego, nie mające dostatecznego oparcia w materiale i na pierwszy rzut oka niewiarygodne, okazały się następnie słuszne" (Kostrzewski 1946-1947, 311). nać tego rodzaju działania (list J. Kostrzewskiego do W. Demetrykiewicza, 28 I 1922, MAK, sygn. SP8/36). Włodzimierz Demetrykiewicz, który już we wrześniu 1921 roku w jednym $z$ listów pisał, że w chwili habilitacji Kozłowskiego o wielu rzeczach nie był należycie poinformowany, a także, że uległ naciskom jego ówczesnych protektorów - profesorów Szajnochy i Hryncewicza, podzielał w tym czasie negatywną opinię Kostrzewskiego o swoim dawnym uczniu (list W. Demetrykiewicza do J. Kostrzewskiego, 15 IX 1921 r., tamże). Jako prawnik przypominał jednak, że propozycja nominowania Leona Kozłowskiego na katedrę we Lwowie została przedstawiona jeszcze przed ogłoszeniem ustawy uniwersyteckiej nakazującej zasięgnięcie opinii profesorów danej specjalności. Uważał więc, że nie można jej było formalnie podważyć, choć podkreślał, że wobec lwowskiego profesora należało stosować otwartą, stałą i wytrwałą krytykę (list W. Demetrykiewicza do J. Kostrzewskiego, 22 II 1922 r., tamże).

Radykalna zmiana opinii Włodzimierza Demetrykiewicza o jego dawnym uczniu miała kilka przyczyn. Jedną z nich była sprawa zdeponowanych w krakowskim muzeum materiałów z Jaskini Mamutowej. W 1921 roku profesor Demetrykiewicz powrócił do zainicjowanego przez Leona Kozłowskiego projektu opracowania kolekcji hrabiego Zawiszy. Kiedy stało się możliwe zakupienie przez Akademię Umiejętności wypożyczonych jej wcześniej materiałów, Demetrykiewicz zwrócił się do Kozłowskiego z pytaniem o termin opracowania i opublikowania kolekcji. Do tego, chcąc pomóc Kozłowskiemu w pozyskaniu materiałów do jego pracy doktorskiej, zobowiązała się przed wojną Akademia (notatka W. Demetrykiewicza, brulion, 1922 r., MAK, sygn. SP8/23). W maju 1921 roku Kozłowski powiadomił Demetrykiewicza o ukończonej już niemal pracy na temat paleolitu. Była to pierwsza w Polsce synteza tej epoki, przetłumaczona później także na język niemiecki (Kozłowski 1922; 1925a $)^{16}$. Kozłowski tłumaczył, że w rozprawie tej fragment dotyczący Jaskini Mamutowej stanowił ważną i nierozerwalną część całości (list L. K. do W. Demetrykiewicza, 28 V 1921 r., MAK, sygn. SP8/36). Jednak Komisja Antropologiczna PAU nie przyjęła wyjaśnień Kozłowskiego. W skierowanym do niego piśmie przewodniczący tej Komisji przypominał, że wraz z wypożyczeniem zbiorów Akademia

16 Po opublikowaniu została ona w ostrych słowach skrytykowana przez Stefana Krukowskiego (Krukowski 1925a; 1925b; Kozłowski 1925c). 
Umiejętności przyjęla na siebie obowiązek przygotowania odrębnej monografii na ich temat. Ponadto, argumentował, w zbiorach pochodzących z Jaskini Mamutowej znajdowały się również materiały neolityczne, które także powinny były zostać uwzględnione w opracowaniu. Zwracając się do Kozłowskiego z prośbą o szybkie przesłanie obiecanego wcześniej tekstu informował, że sprawę wydania rozprawy o paleolicie należy rozpatrywać osobno (pismo Przewodniczącego Komisji Antropologicznej PAU do L. K., Korespondencja Sekretarza Generalnego PAU, Archiwum Nauki PAN i PAU w Krakowie, sygn. KSG 431/1921). Ostatecznie jednak, pomimo przynagleń ze strony Włodzimierza Demetrykiewicza i Komisji Antropologicznej, Leon Kozłowski nie przygotował odrębnej monografii na temat zbiorów hrabiego Zawiszy.

\section{CZLONKOSTWO W AKADEMII UMIEJĘTNOŚCI}

Leon Kozłowski został członkiem korespondentem Polskiej Akademii Umiejętności w 1935 roku. Wcześniej jednakże poruszano możliwość mianowania go współpracownikiem Komisji Antropologicznej PAU. W styczniu 1924 roku Włodzimierz Demetrykiewicz przedstawił listę kandydatów na współpracowników Komisji, w gronie których znaleźli się Bohdan Janusz (1888-1930), Michał Drewko, Stefan Krukowski, Ludwik Sawicki i Zygmunt Zakrzewski (1867-1951). Demetrykiewicz wspomniał wówczas także o Leonie Kozłowskim, ale bez polecenia go (Protokoły Komisji Antropologicznej, Archiwum Nauki PAN i PAU w Krakowie, sygn. PAU W III-46, k. 83'). Oceniając negatywnie naukową działalność swojego dawnego ucznia, Włodzimierz Demetrykiewicz przeciwstawił się projektowi nadania mu przez Polską Akademię Umiejętności nagrody z fundacji Probusa Barczewskiego, za wydaną we Lwowie rozprawę Młodsza epoka kamienna w Polsce (neolit) (Kozłowski 1924; por. Kostrzewski 1925). Nagroda im. Barczewskiego była przyznawana w Akademii za wybitne prace z dziedziny historii oraz, osobno, za dzieła malarskie (Hulewicz 1948, 44-46; Dużyk 1972).

Jednak w 1934 roku to właśnie krakowski profesor zgłosił kandydaturę Kozłowskiego na członka korespondenta PAU, wtedy już nie tylko profesora prehistorii na Uniwersytecie Jana Kazimierza we Lwowie, ale także prezesa Rady Ministrów. Potrzebnego poparcia dwóch innych członków Akademii udzielili profesorowie Julian Pagaczewski (1874-1940) i Jan
Michał Rozwadowski (1867-1935) (pismo W. Demetrykiewicza do Wydziału I PAU, 12 X 1934 r., Archiwum Nauki PAN i PAU w Krakowie, Akta wyboru L. K. na członka korespondenta PAU, Wydział I). W piśmie do Wydziału Filologicznego PAU Włodzimierz Demetrykiewicz, przemilczając wcześniejsze głosy krytyki, tak uzasadniał przedstawianą kandydaturę:

„Tenże [Leon Kozłowski-przyp. aut.] od wielu lat był bardzo czynnym współpracownikiem Komisji Antropologii i Prehistorii w Akademii Umiejętności. Podejmował wiele ważnych badań wykopaliskowych na terenach byłego Królestwa Polskiego i wschodniej Małopolski. Ogłosił drukiem szereg prac archeologicznych, niektóre znacznych rozmiarów. Były one przychylnie przyjmowane i cenione przez krytykę zarówno krajową, jak i zagraniczną (tu można przytoczyć np. Prof. Obermaiera, Menghina, Niderlego etc.). Jedna rozprawa została nawet przetłumaczona na język niemiecki” (tamże).

Kandydaturę Leona Kozłowskiego poparł także Józef Kostrzewski, w tym czasie już członek czynny PAU, wysyłając $w$ tej sprawie telegram i pismo do Krakowa (Akta wyboru L. K. na członka korespondenta PAU, Archiwum Nauki PAN i PAU w Krakowie). Wybór Kozłowskiego na członka Akademii został przeprowadzony $\mathrm{w}$ pierwszym głosowaniu na posiedzeniu Wydziału Filologicznego, w marcu 1935 roku (Protokoły Wydziału I, Archiwum Nauki PAN i PAU w Krakowie, sygn. PAU W I-3, k. 113). W czerwcu tego roku wybór ten został zatwierdzony przez Walne Zgromadzenie Akademii (Majkowska red. 2006, 66).

\section{ZAKOŃCZENIE}

Naukowe związki Leona Kozłowskiego z Krakowem objęły lata 1910-1920 - od rozpoczęcia studiów do uzyskania habilitacji na Uniwersytecie Jagiellońskim. Tylko dziesięciolecie, ale jakże burzliwy i pełen wydarzeń okres. Był to czas zdobywania wykształcenia i zbierania doświadczeń w pracach terenowych. Lata studiów na krakowskiej uczelni, a także nieformalna asystentura w Muzeum Archeologicznym Akademii Umiejętności w Krakowie odegrały ważną, choć często niedocenianą rolę w jego naukowym rozwoju. Młody, zaledwie kilkunastoletni przyszły archeolog przybywając do Krakowa posiadał już wprawdzie pewną wiedzę i doświadczenie wykopaliskowe - prowadził przecież dzięki Erazmowi Ma- 
jewskiemu badania terenowe i publikował w Światowicie. Utrzymywane przez kilka lat bliskie kontakty z krakowskim ośrodkiem archeologii prehistorycznej wywarły jednak przemożny wpływ na jego ukształtowanie jako badacza. Na krakowskiej uczelni Kozłowski poświęcił się studiowaniu nauk przyrodniczych, których znajomość uważał za niezbędną przy badaniu epok kamienia, stanowiących w tym czasie główny przedmiot jego naukowych zainteresowań. Prehistorię poznawał jako asystent profesora Demetrykiewicza w Muzeum Archeologicznym AU i jako słuchacz jego wykładów, a także w czasie dwóch pobytów studyjnych na Uniwersytecie w Tybindze. W Krakowie Leon Kozłowski miał stały i swobodny dostęp do bogatych zbiorów naukowych Akademii Umiejętności. Praca z zabytkami archeologicznymi była ważnym uzupełnieniem słuchanych na uniwersytecie wykładów. Kozłowski konsultował przy tym swoje prace z Demetrykiewiczem i uczestniczył w prowadzonych przez niego badaniach terenowych. Wysłany przez profesora, wraz z Michałem Drewką badał cmentarzyska kultury łużyckiej w okolicach Tarnobrzegu. Prowadził także z Wiktorem Kuźniarem finansowane przez Akademię Umiejętności badania na stanowisku paleolitycznym w Jaksicach. Ponadto, wciąż jeszcze jako student, prowadził samodzielne badania $\mathrm{z}$ ramienia Akademii - najpierw grobowców megalitycznych na Kujawach, a później na stanowisku w Jaskini Mamutowej na Jurze Ojcowskiej.

W Akademii Umiejętności w Krakowie Leon Kozłowski poznał docenta Roberta Rudolfa Schmidta, znawcę paleolitu, wykładającego na Uniwersytecie w Tybindze. Dzięki tej znajomości dwukrotnie wyjechał na studia do Niemiec. Pobyt w Tybindze stał się dla niego okazją do pogłębienia wiedzy z dziedziny geologii i prehistorii, a w zakresie tej drugiej zwłaszcza ze starszej i młodszej epoki kamienia. Podczas wyprawy badawczej ze Schmidtem na Krym i Kau- kaz Kozłowski gromadził zbiory dla Muzeum Akademii Umiejętności.

Okres naukowych związków Leona Kozłowskiego z Krakowem był okresem, w którym tak w podzielonym kraju, jak i na arenie międzynarodowej miały miejsce doniosłe wydarzenia - były to lata Wielkiej Wojny, a w jej następstwie odzyskanie przez Polskę niepodległości. W tym czasie, podobnie zresztą jak wcześniej i później, w życiu młodego badacza sprawy nauki przeplatały się z zaangażowaniem $\mathrm{w}$ politykę, zmieniając niejednokrotnie ustalone wcześniej plany. Studia odbywał z przerwami spowodowanymi przez wybuch wojny, udział w walkach i działalność niepodległościową. Wojna przeszkodziła mu także w obronie dysertacji na Uniwersytecie Jagiellońskim. Zagrożony z powodu zaangażowania $\mathrm{w}$ działalność polityczną, zmuszony do opuszczenia Galicji, wyjechał do Tybingi i tam obronił napisaną wcześniej rozprawę doktorską. Pracę tę napisał w Warszawie, na podstawie zbiorów Muzeum Majewskiego. Na Uniwersytecie Jagiellońskim uzyskał natomiast habilitację. Wraz z nią zakończył się okres jego bliskich związków naukowych z Krakowem. Pozostanie tam nie niosło ze sobą perspektywy dalszego rozwoju kariery naukowej. Uniwersytet Jagielloński oferował mu jedynie niepewne i niedochodowe, a przy tym absorbujące stanowisko docenta prywatnego, a prehistoria w Akademii Umiejętności wciąż była dyscypliną niedostatecznie docenianą i finansowaną. W niedługim czasie objął katedrę prehistorii we Lwowie, z którą, z przerwami wynikającymi z zaangażowania w działalność polityczną, związany był do wybuchu II wojny światowej. Wkrótce po objęciu katedry we Lwowie jego kontakty z Uniwersytetem Jagiellońskim i Akademią Umiejętności uległy osłabieniu, a właściwie ustały. Dopiero w 1935 roku został wybrany członkiem korespondentem Polskiej Akademii Umiejętności.

\section{BIBLIOGRAFIA}

Abramowicz A. (1991). Historia archeologii polskiej XIX i XX wiek. Warszawa-Łódź: Instytut Historii Kultury Materialnej PAN.

Antoniewicz W. (1920). Cmentarzysko ciałopalne z końca epoki brązowej w Skotnikach pod Krakowem. Prace i Materiaty Antropologiczno-Archeologiczne i Etnograficzne, 1, 53-94.
Bieniarzówna J., Małecki J. (1979). Dzieje Krakowa. Kraków w latach 1796-1818. Kraków: Wydawnictwo Literackie.

Bieńkowski W. (1983). Rola Krakowa w polskim życiu naukowym. W: J. Małecki (red.), Kraków na przełomie XIX i XX wieku. Materiaty sesji naukowej z okazji Dni 
Krakowa w 1981 roku (19-44). Kraków: Wydawnictwo Literackie.

Bilas N. (2010). Leon Kozłowski - profesor Katedry Archeologii Prehistorycznej ze specjalnym uwzględnieniem prehistorii ziem polskich (1921-1939) Uniwersytetu Jana Kazimierza we Lwowie. W: S.K. Kozłowski, O. Sytnyk, (red.), Profesor Leon Kozłowski (328-367). Lwów-Warszawa: Uniwersytet Warszawski.

Bilas N. (2018). Archaeological Research at the Lvov University: Interwar Period. W: D.H. Werra, M. Woźny (red.), Between History and Archaeology. Papers in honour of Jacek Lech (435-453). Oxford: Archaeopress.

Corpus studiosorum... (2009). Corpus studiosorum Universitatis Iagellonicae 1850/51-1917/18, K-Ł. W: K. Stopka (red.), Z prac Archiwum Uniwersytetu Jagiellońskiego. Seria C(3). Kraków: Towarzystwo Wydawnicze „Historia Iagellonica”.

Demetrykiewicz W. (1897). Cmentarzyska i osady przedhistoryczne w Tarnobrzeskiem. Materiaty Antropologiczno-Archeologiczne i Etnograficzne, 2, 135-156.

Dużyk J. (1972). Z dziejów nagrody im. Probusa Barczewskiego. Rocznik Biblioteki PAN w Krakowie, 18, 149197.

Dybiec J. (1979). Finansowanie nauki i oświaty w Galicji. 1860-1918. Kraków.

Dybiec J. (1993). Polska Akademia Umiejętności 18721952. Kraków.

Gedl M. (1971). Kierunek archeologii Polski na Uniwersytecie Jagiellońskim przed 1945 rokiem. Światowit, 32, 187-197.

Gedl M. (2000). Włodzimierz Demetrykiewicz (18591937). W: J. Dybiec (red.), Uniwersytet Jagielloński. Złota księga Wydziału Historycznego (130-137). Kraków: Księgarnia Akademicka.

Godlewski L. (2010). Studia Leona Kozłowskiego. W: S.K. Kozłowski, O. Sytnyk (red.), Profesor Leon Kozłowski (303-327). Lwów-Warszawa: Uniwersytet Warszawski.

Hulewicz J. (1948). Polska Akademia Umiejętności 18731948. Zarys dziejów. Kraków: Polska Akademia Umiejętności.

Jażdżewski K., Jędruszczak T. (1970). Kozłowski Leon Tadeusz (1892-1944). W: Polski Słownik Biograficzny, 15 (19-21). Wrocław: Zakład Narodowy im. Ossolińskich - Wydawnictwo Polskiej Akademii Nauk.

Kaczorowski G. (2010). Badania terenowe i publikacje Leona Kozłowskiego. W: S.K. Kozłowski, O. Sytnyk (red.), Profesor Leon Kozłowski (409-439). LwówWarszawa: Uniwersytet Warszawski.
Kot M. (2019). Historia badań w jaskini Gvardjilas Klde w Gruzji. W: M. Kot et al. (red.), Jaskinia Gvardjilas Klde w Gruzji (54-95). Opracowanie wydane w stulecie badań polskiego archeologa Stefana Krukowskiego. Warszawa: Państwowe Muzeum Archeologiczne w Warszawie i Wydawnictwo Uniwersytetu Warszawskiego.

Kostrzewski J. (1922). Rec.: L. Kozłowski, Groby megalityczne na wschód od Odry, Kraków 1921. Wiadomości Archeologiczne, 7, 168-174.

Kostrzewski J. (1925). Rec.: L. Kozłowski, Młodsza epoka kamienna w Polsce, Lwów 1924. Wiadomości Archeologiczne, 9(3-4), 262-296.

Kostrzewski J. (1946-1947). Śp. prof. dr Leon Kozłowski. Przeglad Archeologiczny, 7, 311-312.

Kostrzewski J. (1949). Dzieje polskich badań prehistorycznych. Poznań.

Kostrzewski J. (1970). Z mego życia. Wrocław.

Kozłowski L. (1911a). Sprawozdanie tymczasowe z poszukiwań archeologiczno-przedhistorycznych w dorzeczu Przemszy, Dłubni i Szreniawy. Przedstawione na posiedzeniu 14 stycznia 1911 r. KomisjiAntropologicznej Towarzystwa Naukowego Warszawskiego (z 5-ma mapkami). Światowit, 9, 79-86.

Kozłowski L. (1911b). Sprawozdanie tymczasowe z poszukiwań archeologiczno-przedhistorycznych w dorzeczu Przemszy i Dłubni. Przedstawił p. E. Majewski. Posiedzenie z dnia 20 stycznia 1911 r. Sprawozdania z posiedzeń Towarzystwa Naukowego Warszawskiego, Dziat II. Wydziat nauk antropologicznych, społecznych, historii i filozofii, 4(1), 42-47.

Kozłowski L. (1912). Cmentarzysko ciałopalne w Iwanowicach na Górze Klin (pow. Miechowski, g. Kielecka). Światowit, 10, 25-48.

Kozłowski L. (1913a). Siedziba neolityczna na „Babiej Górze" w Iwanowicach pow. Miechowski gub. Kielecka. Światowit, 11, 15-41.

Kozłowski L. (1913b). Jama mieszkalna na górze Klin w Iwanowicach (pow. Miechowski, gub. Kielecka). Światowit, 11, 61-76.

Kozłowski L. (1917). Badania archeologiczne na górze Klin w Iwanowicach, powiatu Miechowskiego. Prace Towarzystwa Naukowego Warszawskiego, II. Wydziat nauk antropologicznych, społecznych, historii i filozofi, 17. Warszawa.

Kozłowski L. (1921). Groby megalityczne na wschód od Odry. Prace i Materiaty Antropologiczno-Archeologiczne i Etnograficzne, 2, 1-63.

Kozłowski L. (1922). Starsza epoka kamienna w Polsce (Paleolit). Poznań. 
Kozłowski L. (1923). Epoka kamienia na wydmach wschodniej części Wyżyny Małopolskiej. Lwów-Warszawa.

Kozłowski L. (1924). Młodsza epoka kamienna w Polsce (neolit). Lwów.

Kozłowski L. (1925a). Die ältere Steinzeit in Polen. Leipzig.

Kozłowski L. (1925b). W odpowiedzi p. Sawickiemu słów kilka. Przegląd Archeologiczny, 2(1922-1924), 323325 .

Kozłowski L. (1925c). Odpowiedź na recenzję p. St. Krukowskiego o mej pracy o polskim paleolicie. Przegląd Archeologiczny, 2(1922-1924), 239-242.

Kozłowski L. (2005). Autobiografia Leona Kozłowskiego zapisana w więzieniu na Łubiance. W: M. Kozłowski, Sprawa premiera Leona Kozłowskiego. Zdrajca czy ofiara (216-227). Warszawa: Wydawnictwo ISKRY.

Kozłowski L., Kuźniar W. (1914). Paleolit w Jaksicach nad Wisłą. Materiały Antropologiczno-Archeologiczne i Etnograficzne, 13, 3-9.

Kozłowski M. (2005). Sprawa premiera Leona Kozłowskiego. Zdrajca czy ofiara. Warszawa: Wydawnictwo ISKRY.

Kozłowski S.K. (1993). Pierwsi profesorowie. W: S.K. Kozłowski, J. Kolendo, Dzieje archeologii na Uniwersytecie Warszawskim (53-70). Warszawa: Uniwersytet Warszawski.

Kozłowski S.K. (1996). Jak Erazm Majewski wyciągnął Leona Kozłowskiego z kryminału. W: S.K. Kozłowski, J. Lech (red.), Erazm Majewski $i$ warszawska szkoła prehistoryczna na początku XX wieku (97-98). Warszawa: Wydawnictwo Naukowe PWN.

Kozłowski S.K. (2007). Stefan Krukowski. Narodziny giganta. Warszawa: Państwowe Muzeum Archeologiczne i Stowarzyszenie Naukowe Archeologów Polskich Oddział w Warszawie.

Kozłowski S.K. (2010). Leon. W: S.K. Kozłowski, O. Sytnyk (red.), Profesor Leon Kozłowski (205-302). Lwów-Warszawa: Uniwersytet Warszawski.

Krukowski S. (1925a). Recenzja pracy L. Kozłowskiego o paleolicie polskim i uwagi o materiałach, uwzględnionych przez tegoż. Przegląd Archeologiczny, 2(1922-1924), 147-160.

Krukowski S. (1925b). O replice p. L. Kozłowskiego na moją recenzję jego pracy o paleolicie Polski. Przegląd Archeologiczny, 2(1922-1924), 320-322.

Kutrzeba S. (1939). Polska Akademia Umiejętności. 18721938. Kraków: Polska Akademia Umiejętności.

Lech J. (1996). Erazm Majewski jako archeolog i tradycja polskich badań epoki kamienia. W: S.K. Kozłowski, J. Lech (red.), Erazm Majewski i warszawska szkoła prehistoryczna na początku XX wieku (45-77). Warszawa: Wydawnictwo Naukowe PWN.

Lech J. (1997-1998). Between captivity and freedom: Polish archaeology in the $20^{\text {th }}$ century. Archaeologia Polona, $35-36,25-222$.

Lech J. (2000). Kultura archeologiczna: z dziejów jednego pojęcia. W: S. Tabaczyński (red.), Kultury archeologiczne a rzeczywistość dziejowa (151-183). Warszawa: Wydawnictwo Naukowe PWN.

Lech J. (2001). Archeologia Jury Ojcowskiej w zarysie. W: J. Lech, J. Partyka (red.), Z archeologii Ukrainy i Jury Ojcowskiej (127-182). Ojców: Muzeum im. Profesora Władysława Szafera (Ojcowski Park Narodowy).

Lech J. (2006). Z badań polsko-ukraińskich związków w archeologii do II wojny światowej. Przegląd Archeologiczny, 54, 5-59.

Lech J., Piotrowska D. (2006). Leon Kozłowski i jego związki z Jurą Ojcowską. W: J. Lech, J. Partyka (red.), Jura Ojcowska w pradziejach $i$ w poczatkach państwa polskiego (159-192). Ojców: Ojcowski Park Narodowy.

Majkowska R. (red.). (2006). Poczet członków Akademii Umiejętności i Polskiej Akademii Umiejętności w latach 1872-2000. Kraków: Polska Akademia Umiejętności.

Michalewska K. (1997). Wydział Filozoficzny Uniwersytetu Jagiellońskiego (1849-1945). W: J. Michalewicz (red.), Inwentarz akt wydziałów i studiów UniwersytetuJagiellońskiego 1850-1939(1954).ZpracArchiwum Uniwersytetu Jagiellońskiego, Seria A(7) (227-284). Kraków: Archiwum Uniwersytetu Jagiellońskiego.

Modrzewska H. (1983/1987). Erazm Majewski badacz starożytności i twórca Muzeum Archeologicznego w Warszawie w świetle swego „Notatnika”. Wiadomości Archeologiczne, 48(2), 163-191.

Nosek S. (1967). Zarys historii badań archeologicznych w Małopolsce. Wrocław-Warszawa-Kraków: Zakład Narodowy im. Ossolińskich - Wydawnictwo Polskiej Akademii Nauk.

Perkowska U. (1990). Uniwersytet Jagielloński w latach I wojny światowej, Kraków.

Perkowska U. (2007). Corpus Academicorum Facultatis Philosophiae Universitatis Iagellonicae 1850-1945. Z prac Archiwum Uniwersytetu Jagiellońskiego, Seria F(6). Kraków: Księgarnia Akademicka.

Piotrowska D. (2006). Stefan Krukowski, Jura Ojcowska i archeologia w świetle listów i dokumentów ze zbiorów Państwowego Muzeum Archeologicznego w Warszawie. W: J. Lech, J. Partyka (red.), Jura Ojcowska $w$ pradziejach $i$ w poczatkach państwa polskiego (193-224). Ojców: Ojcowski Park Narodowy. 
Sawicki L. (1925). Rec. z pracy: L. Kozłowski, Epoka kamienia na wydmach wschodniej części Wyżyny Małopolskiej, Lwów - Warszawa 1923. Przegląd Archeologiczny, 2(1922-1924), 243-255.

Spis wykładów... (1910). Spis wykładów w półroczu zimowym. Rok szkolny 1910/11. Kraków: C. K. Uniwersytet Jagielloński.

Spis wykładów... (1911a). Spis wykładów w pótroczu letnim. Rok szkolny 1910/11. Kraków: C. K. Uniwersytet Jagielloński.

Spis wykładów... (1911b). Spis wykładów w pótroczu zimowym. Rok szkolny 1911/12. Kraków: C. K. Uniwersytet Jagielloński.

Spis wykładów... (1912). Spis wykładów w pótroczu letnim. Rok szkolny 1911/12. Kraków: C. K. Uniwersytet Jagielloński.

Sprawozdania z posiedzeń... (1914). Sprawozdania z posiedzeń Komisji antropologicznej odbytych w r. 1912 i 1913. Materiaty Antropologiczno-Archeologiczne i Etnograficzne, 13, 8-21.

Sprawozdania z posiedzeń... (1919). Sprawozdania z posiedzeń Komisji antropologicznej jakie odbyły się w latach 1914-1919. Materiaty Antropologiczno-Archeologiczne i Etnograficzne, 14, 6-26.

Sprawozdanie... (1913). Sprawozdanie Sekretarza Generalnego z czynności Akademii od kwietnia 1912 do kwietnia 1913. Rocznik Akademii Umiejętności w Krakowie, R. 1912/1913, 72-145.

Sprawozdanie... (1914). Sprawozdanie Sekretarza Generalnego z czynności Akademii od kwietnia 1913 do kwietnia 1914. Rocznik Akademii Umiejętności w Krakowie, R. 1913/1914, 8-82.

Sprawozdanie... (1939). Sprawozdanie z czynności i wydawnictw PAU od czerwca 1937 do czerwca 1938.
RocznikPolskiejAkademii Umiejętności, R. 1937/1938, 3-66.

Stachowska K. (1990). Polska Akademia Umiejętności. W: B. Sordylowa (red.), Stownik Polskich Towarzystw Naukowych 2(1), (43-56). Wrocław-Warszawa: Zakład Narodowy im. Ossolińskich.

Stolpiak B. (1984). Rozwój prahistorii polskiej w okresie 20-lecia międzywojennego. Część I: 1918-1928. Poznań: Wydawnictwo Naukowe UAM.

Stopka K., Banach A.K., Dybiec J. (2000). Dzieje Uniwersytetu Jagiellońskiego. Kraków: Wydawnictwo Uniwersytetu Jagiellońskiego

Sytnyk O. (2006). Katedry archeologii Uniwersytetu Lwowskiego w latach 1905-2005. Przeglad Archeologiczny, 54, 125-159.

Sytnyk O. (2010). Kulturalno-historyczne tło rozwoju badań archeologicznych we Lwowie w okresie międzywojennym. W: S.K. Kozłowski, O. Sytnyk (red.), Profesor Leon Kozłowski (82-204). Lwów-Warszawa: Uniwersytet Warszawski.

W sprawie docentury prywatnej... ([1919-1920]). W sprawie docentury prywatnej na uniwersytetach polskich. Memoriat Towarzystwa docentów prywatnych Uniwersytetu Jagiellońskiego w Krakowie. Maszynopis. Archiwum UJ, sygn. S II 583.

Tymczasowy skład... (1920). Tymczasowy skład Państwowego Grona Konserwatorów Zabytków Przedhistorycznych. Wiadomości Archeologiczne, 5, 82-83.

Woźny M. (2018). Włodzimierz Demetrykiewicz (18501937). Prehistoryk z przełomu epok. Kraków: Polska Akademia Umiejętności.

Wrońska J. (1986). Archeolodzy warszawscy na poczatku XX wieku. Wrocław: Zakład Narodowy im. Ossolińskich.

\section{MARZENA WOŹNY}

\section{LEON KOZŁOWSKI (1892-1944): THE KRAKÓW PHASE IN THE LIFE OF THE RESEARCHER, SOLDIER, AND POLITICIAN}

\section{SUMMARY}

Leon Kozłowski, the outstanding prehistorian and author of numerous academic publications - including several synthetic monographs on prehistoric periods in Polish lands - was also a soldier, politician, and the Prime Minister of the Polish government in 1934-1935. Kozłowski was linked mostly with Warsaw, where he spent his youth and was actively engaged in politics, and with Lwów/Lviv, where he held the chair of prehistory at the Jan Kazimierz University from 1921 to 1939 (with a break for his political activity in 1931-1935). However, his academic career and 
political involvement were also shaped by Kraków and its two important institutions: the Jagiellonian University and the Academy of Arts and Sciences.

Leon Kozłowski lived in Kraków from 1910 to 1920 , from the beginning of his studies to the time he obtained his postdoctoral thesis at the Jagiellonian University. Thus this was a period when he gained both knowledge and practical experience. His studies and unofficial assistant lectureship at the Archaeological Museum of the Academy of Arts and Sciences played an important part in his academic development. He focused on the natural sciences as he considered them indispensable to research on the Stone Age, his main interest at that time. To a lesser extent he concentrated on prehistory. He learnt the latter as a student and assistant of Prof. Włodzimierz Demetrykiewicz (1859-1937) at the Archaeological Museum of the Academy of Arts and Sciences and then during his two stays at the University of Tübingen.

Prof. Demetrykiewicz gave Kozłowski free access to the rich collections of the Academy of Arts and Sciences, for he viewed the direct study of prehistoric artefacts as a valuable complement to university lectures. He supported his young assistant in his plans for research abroad. Kozłowski consulted him about his own academic work, participated in his tutor's excavations and, at his request, joined Michał Drewko (1887-1964) in exploring Lusatian cemeteries near Tarnobrzeg. Moreover, on behalf of the Academy of Arts and Sciences, Kozłowski excavated a palaeolithic site in Jaksice (former Miechów district) with Wiktor Kuźniar and carried out unassisted exploration of megalithic graves in Kuyavia and a site in the Mammoth Cave.

At the Academy of Arts and Sciences, Leon Kozłowski met Associate Professor Robert Rudolf Schmidt (18821950), an expert in the palaeolithic and a lecturer at the University of Tübingen. Their acquaintance allowed him to study twice in Germany. While there, Kozłowski maintained regular contact with Prof. Demetrykiewicz. Later on, when he accompanied Schmidt on a scientific expedition to the Crimea and the Caucasus, he corresponded regularly with his former tutor, giving him an account of the exploration. During that expedition, he collected finds for the Museum of the Academy in Kraków.

Major events took place in the Polish lands and abroad while Kozłowski was studying in Kraków. He had to change his plans several times, alternating his academic career with his involvement in politics. His studies were interrupted by the outbreak of the First World War and the struggle for Polish independence. The war also prevented his doctoral defence at the Jagiellonian University. Forced to go into hiding and to leave Galicia (then the partition of Poland under Austrian rule) because of his political activity, he moved to Tübingen and defended his doctoral thesis there. He had initially intended to base the dissertation on finds from Count Jan Zawisza's collection brought to Kraków, but he ultimately wrote it in Warsaw, using the collection of the Erazm Majewski Museum instead.

The postdoctoral degree granted to Leon Kozłowski at the Jagiellonian University marked the end of his close academic relationship with Kraków. A further stay in that city did not promise scholarly advancement. The Jagiellonian University could offer him only the insecure post of supernumerary associate professor, while prehistory at the Academy of Arts and Sciences was not yet sufficiently appreciated and financed. Even before his postdoctoral degree, Kozłowski moved to Warsaw, hoping to become an assistant, or rather a successor, to Erazm Majewski as the head of prehistoric archaeology at the University of Warsaw. The plan fell through, but Kozłowski soon took the chair of prehistory at the Jan Kazimierz University in Lviv. He remained there until the Second World War, with a break for his political responsibilities. His contacts with the Jagiellonian University and the Academy of Arts and Sciences loosened and then practically ceased. It was only in 1935 that he was elected a corresponding member of the Academy.

Otrzymano (Received): 06.06.2020; zrecenzowano (Revised): 1.09.2020; zaakceptowano (Accepted): 10.09.2020

Adres Autorki:

Dr Marzena Woźny

Muzeum Archeologiczne w Krakowie

ul. Senacka 3, 31-002 Kraków

e-mail: marzenawoz@wp.pl

(iD https://orcid.org/0000-0002-3057-9231 